OS ESPAÇOS LIVRES DE EDIFICAÇÃO NAS PERIFERIAS URBANAS

UM DIAGNÓSTICO PRELIMINAR EM SÃO PAULO E SALVADOR

Angelo Serpa

\title{
PESQUISA
}





\section{ANGELO SERPA}

Angelo Serpa - Doutor em Planejamento Paisagístico e Ambiental pela Universidade de Agronomia de Viena, professor adjunto do Departamento de Ceografia e do mestrado em arquitetura e urbanismo da Universidade Federal da Bahia 


\section{RESUMO}

O artigo trata dos espaços livres de edificação nas periferias urbanas e os mecanismos de apropriação social dos espaços públicos pela população de bairros periféricos em São Paulo e Salvador. Discute também a relação sociedade/espaço baseado na interpretação dos conflitos entre as esferas pública e privada no cotidiano da cidade contemporânea.

\section{ABSTRACT}

The purpose of the present paper is to analyse the existing open spaces in the periphery of São Paulo and Salvador as well the social use of the public urban areas. We try to clarify the society/space relationship too, based on the interpretation of the conflicts between private and social life in the contemporaneous city. 
MACEDO, S. S. Espaços livres. Revista Paisagem e Ambiente Ensaios, v. 7, FAUUSP, São Paulo, p. 16, 1995.
A lei 8.211/93 é uma lei de zoneamento que cria uma Zona de Uso Predominantemente Industrial (ZUPI), numa área de mais de 4 milhões de metros quadrados, para a concentraçāo de empresas com capacidade de gerar 70 mil novos empregos. As outras duas leis, também leis de zoneamento, criam duas Áreas de Proteçāo Ambiental APA da Mata e Parque do Carmo e Mata do Iguatemi -, impedindo a destruição de 9 milhōes de metros quadrados de reserva ecológica (leis 6.409 .89 e $8.284 / 93)$.

\section{INTRODUÇÃO}

Os espaços livres, que podem assumir no contexto urbano a forma de ruas, praças, largos, pátios, quintais, parques, jardins, terrenos baldios, corredores externos, vilas e vielas ${ }^{1}$, são a matéria-prima do paisagismo urbano. A hierarquização destes espaços é importante não tanto por sua categorização, mas sim pela noção de conjunto que ela evoca, a partir da definição dos limites geográficos para a sua análise. É na contextualização das categorias de análise que os espaços livres ganham o aspecto de "sistema"

\section{O CASO DE ITAQUERA E GUAIANAZES EM SÃO PAULO}

A zona leste de São Paulo e, nela inseridos, os bairros de Itaquera e Guaianazes, possui características de cidade-dormitório, sem um pólo de desenvolvimento e produção própria, abrigando mais de um terço dos 9,5 milhões de habitantes da cidade. As estatísticas apontam uma média de apenas 16 empregos para cada 100 habitantes, enquanto a média da cidade é de 50 para 100 e a do centro de 200 para cada 100 moradores. Tais fatos caracterizam a zona leste de São Paulo como espaço periférico e, por que não dizer, marginal, dentro do contexto da metrópole paulistana.

Situados numa das últimas áreas de expansão urbana da cidade de São Paulo, os bairros de Itaquera e Guaianazes assistem, nas últimas décadas, a chegada de milhares de novos moradores, com a implantação, pelas Companhias Habitacionais do Estado, dos conjuntos habitacionais Manoel da Nóbrega, José de Anchieta e José Bonifácio e, mais recentemente, dos conjuntos do Projeto Cingapura, do governo municipal. Com a criação do Pólo Industrial e Ecológico da Zona Leste ${ }^{2}$ consolida-se a tendência de industrializa- 
ção verificada nos últimos $\operatorname{anos}^{3}$ com a instalação de indústrias metalúrgicas e de cimento.

\section{PARQUES E PRAÇAS}

O parque do Carmo (Foto 1), um parque metropolitano localizado na zona leste de São Paulo, foi instalado nas antigas terras da fazenda do Carmo, de propriedade de Oscar Americano. Essa área de $1.500 .359 \mathrm{~m}^{2}$, desapropriada pelo prefeito Olavo Setúbal, pertencia a uma gleba muito maior, de propriedade da Companhia Brasileira de Projetos e Obras $(\mathrm{CBPO})^{4}$ Por suas dimensões e pelas diferentes alternativas de lazer que oferece, o parque atrai levas de moradores
Exemplos de indústrias instaladas no bairro de Itaquera antes da aprovação do projeto de lei: Vulcânia S/A, Concremix S/A, Niquelação Peres Ltda, Cimetal Ltda, Metalúrgica Gaiser Ltda, Magnum Metal Ltda, Perpal Ind. e Com. de Metais Ltda, Plast Seven Indústria de Plásticos Ltda, etc.

KLIASS, R. G.

Parques urbanos de São Paulo. São Paulo: 1994, p. 177.

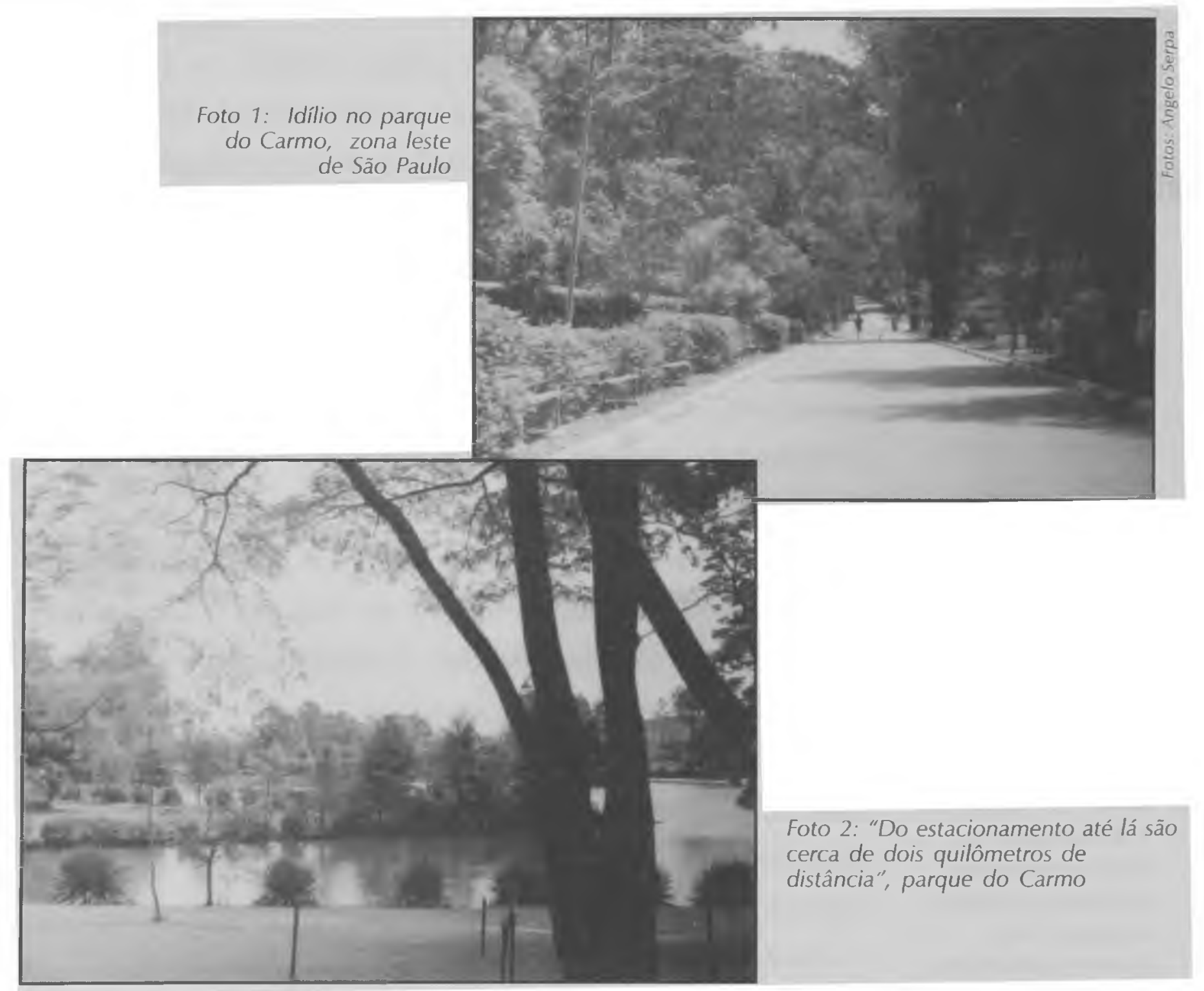


SECAWA, H. Do amor ao público. Jardins no Brasil 1779-1911: São Paulo: 1994, p. 23 e 25 - FAUUSP de bairros periféricos como Itaquera, Guaianazes e São Miguel Paulista. A freqüência é maior nos finais de semana. Para a arquiteta Ayako Nishikawa, do Departamento de Áreas Verdes do município, o conflito institucional entre o Depave e a administração regional de Itaquera-Guaianazes impede um uso mais racional do parque do Carmo. Ela acha que tudo no parque leva a marca do improviso e reclama da mádistribuição dos equipamentos: "O local onde fizeram o anfiteatro foi bem escolhido, mas não pensaram no acesso dos usuários. Do estacionamento até lá são cerca de dois quilômetros de distância." (Foto 2)

No tocante às praças, a divisão de responsabilidades entre o Depave e as administrações regionais obedece a uma norma informal (não é lei todavia) de que áreas com menos de $5.000 \mathrm{~m}^{2}$ são de responsabilidade das administraçōes, que devem implantá-las e mantê-las, não havendo necessidade de projeto arquitetônico e paisagístico. A implantação de praças pelas administrações regionais obedece, principalmente, a critérios políticos, ditados pela política do "é dando que se recebe"

"A praça é um espaço ancestral que se confunde com a própria origem do conceito ocidental de urbano (...) a cultura popular não oficial dispunha na idade média e ainda durante o renascimento de um território próprio: A praça pública, e de uma data própria: Os dias de festa e de feira."5

Enquanto as praças do centro de Itaquera conservam ainda esse ar de "festa e de feira", de exercício de cidadania, muito relacionado ao passear descompromissado por caminhos sinuosos e arborizados (em meio a outros que passam ou sentam-se nos bancos das alamedas), as praças mais afastadas do centro do bairro, na nova "cidade-Cohab", tornam-se espaços desertos, cegos das suas possibilidades. 
"As praças centrais possuem mais dinâmica de passagem que de estagem. E assim devem ser consideradas: um acidente espacial de ruptura com o volume edificado. Existem pessoas, objetos constantes e imóveis, ou móveis, dentro de um pequeno espaço, sendo entornados por um ir e vir incessante de passantes e momentaneamente apreciadores deste situacionismo mutavelmente decadente, renovador, vindo a criar novos estímulos nestes espaços, onde, por outro lado, a idéia de descansar, repousar, não se dá só ao nível de sair da área de circulação, pois o elemento pedestre passante é imagem (seja qual for o gesto, a atitude, a pressa, a vinda, a fala, o vestir, etc.) a ser

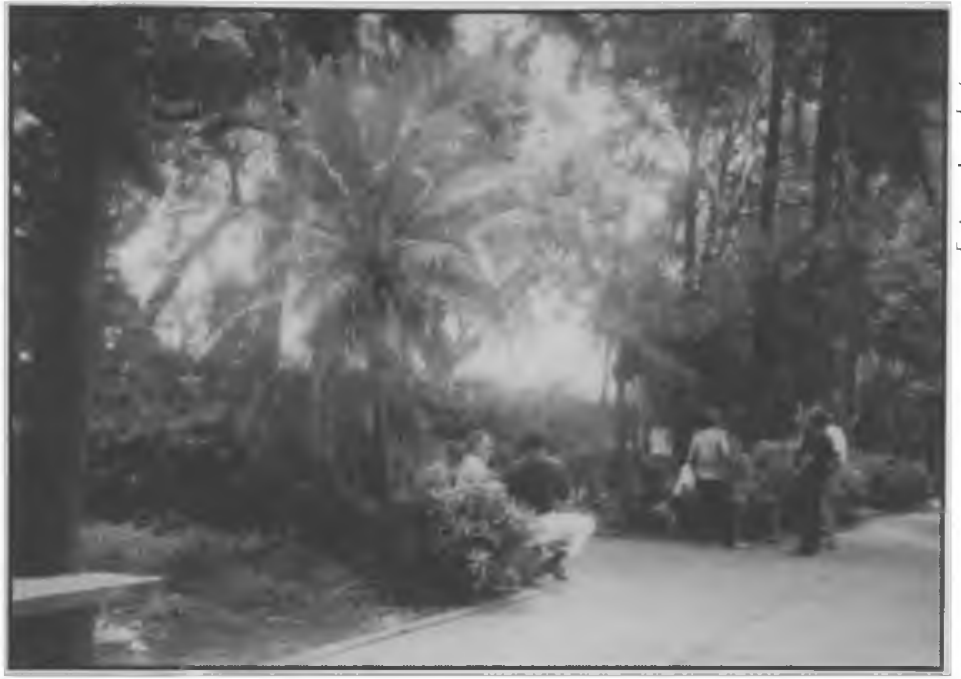

Foto 3: Praça da Estação: Lugar de encontro para senhores de meia-idade

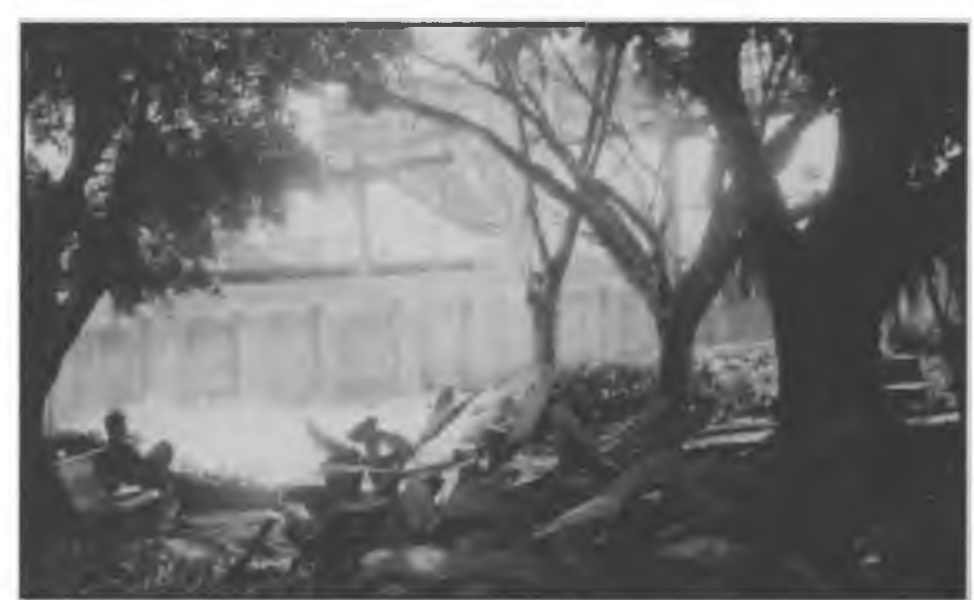

Foto 4: Praça da Estação: Ares de "natureza" observada por parte do estante na praça." 6

A praça da Estação é esse lugar de encontro para senhores de idade que jogam cartas e conversa fora com os amigos (Foto 3). Também vem gente das lojas próximas, sentar nos bancos e aproveitar a hora do "almoço-sanduíche" sob a sombra das árvores. Para o "cidadão-Cohab", a praça da

6 GOULART, P. C. A. Pracidade. Trabalho de Graduação Interdisciplinar. FAUUSP, São Paulo, p. 40. Estação tem até ares de "natureza" (Foto 4). Para os moradores do Conjunto José Bonifácio e redondezas faltam árvores de grande porte, bancos e equipamentos para as crianças nas praças novas. É o caso das praças Bom Pastor e Carmen Verdegay, ambas localizadas no conjunto (Fotos 5 e 6). 
OS ESPACOS LIVRES DE EDIFICAÇÃO NAS

PERIFERIAS URBANAS UM DIAGNOSTICO

PRELIMINAR EM SÄO PAULO E SALVADOR
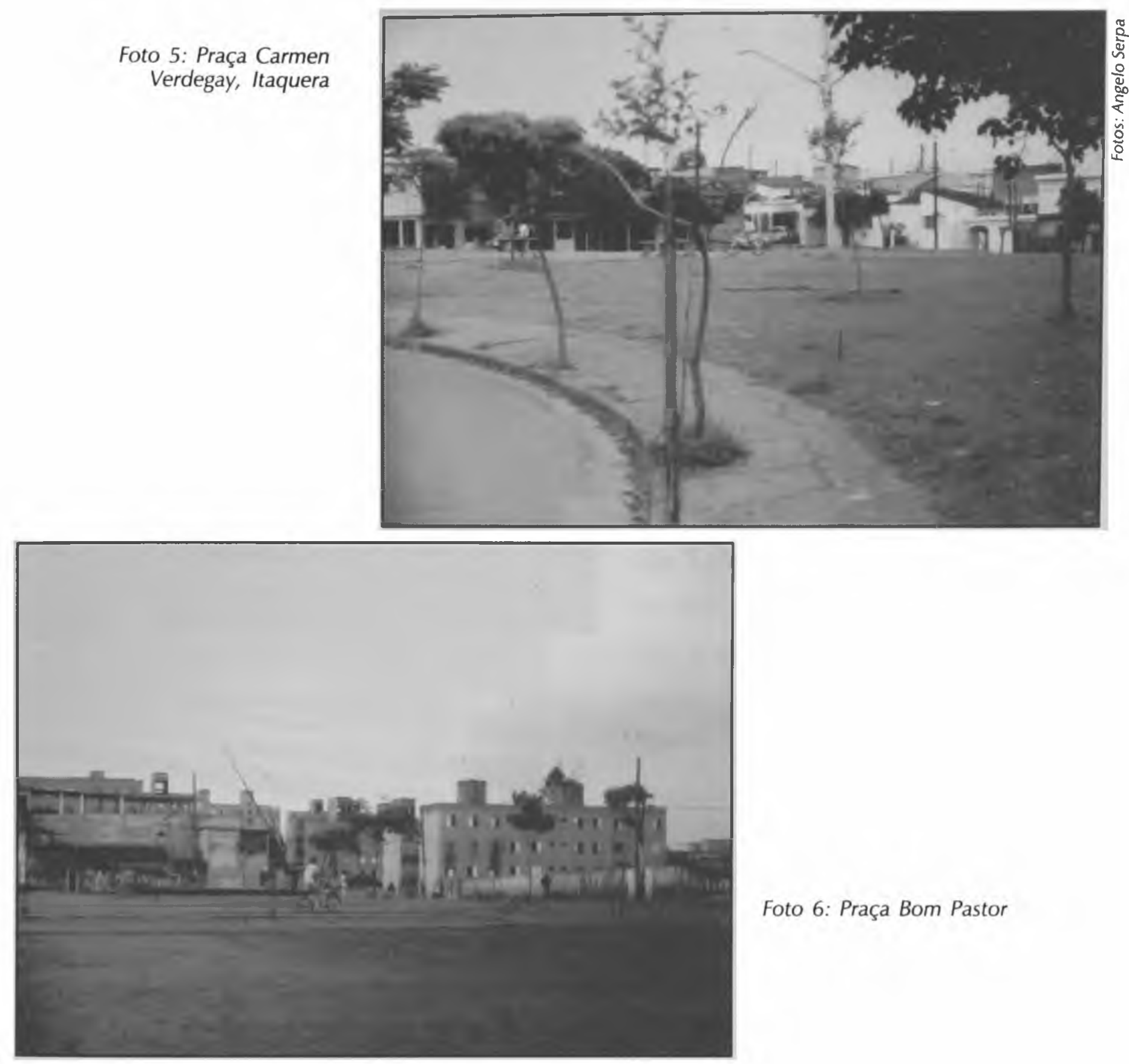

Foto 6: Praça Bom Pastor

A iniciativa dos moradores compensa, em alguns casos, a falta de cuidados da administração regional, mas isso nem sempre funciona a médio prazo:

"Para plantar árvores nessa praça em frente de casa (Foto 7), a regional veio aqui, fez reuniōes com os moradores. $\mathrm{Na}$ época houve toda uma conscientização, todo mundo plantando. Mas algumas pessoas começaram a jogar lixo e entulho naquela área. O pessoal do entorno reclamava, perguntava àquelas pessoas se não viam que aquilo ali era 
uma praça. Só que essas pessoas que tomavam frente das coisas, que iạm lá e cuidavam daquele espaço, estão cansadas." (Maria do Carmo Camargo, 36 anos, moradora de Itaquera.)

Samuel Firmo, que foi funcionário da Administração Regional de ItaqueraGuaianazes na gestão da prefeita Luiza Erundina, conta o que era feito na época contra os "jogadores de entulho": "Aqueles canteiros centrais da avenida João Batista Conti foram feitos para que o pessoal não jogasse entulho ali. Na Cohab os caras fazem uma reforminha e não sabem onde jogar o entulho. Aí nós

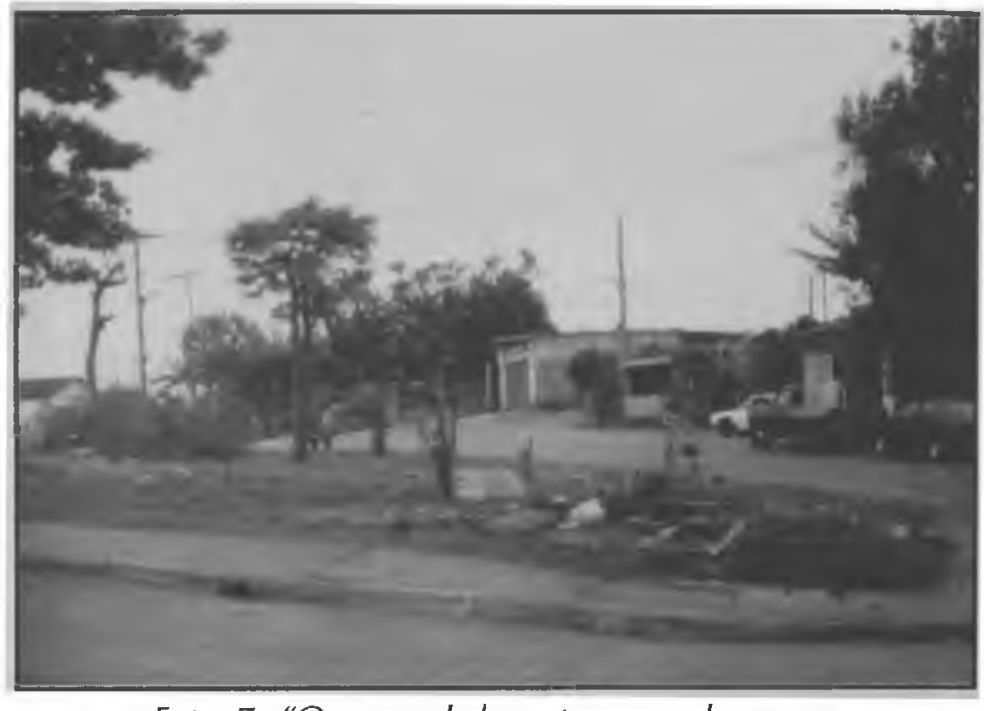

Foto 7: "O pessoal do entorno reclamava, perguntava àquelas pessoas se não viam que aquilo ali era uma praça" fizemos o canteiro. Porque aí ninguém teve mais a cara de pau de jogar entulho no meio do canteiro."

A praça Brasil (Fotos 8 e 9), também situada no Conjunto José Bonifácio, tem seu uso ligado ao terminal de ônibus e às lojas existentes no local. É uma praça grande (20.331 m²), com anfiteatro e playground para as crianças, mas subutilizada pelos moradores do conjunto. É mais um lugar de "passagem", do que um lugar de "estagem"

Os dados fornecidos pela Administração Regional de Itaquera-Guaianazes mostram que de 1989 a 1994 foram implantados cerca de $139.305 \mathrm{~m}^{2}$ de áreas ajardinadas nestes bairros. Para a arquiteta Laís Monteiro da Silva, do Depave, a manutenção destas praças acaba sendo complicada porque não há um responsável direto por elas: "Antes existia a figura do jardineiro, mas hoje isso não existe mais. $A$ administração regional tem um engenheiro-agrônomo e 


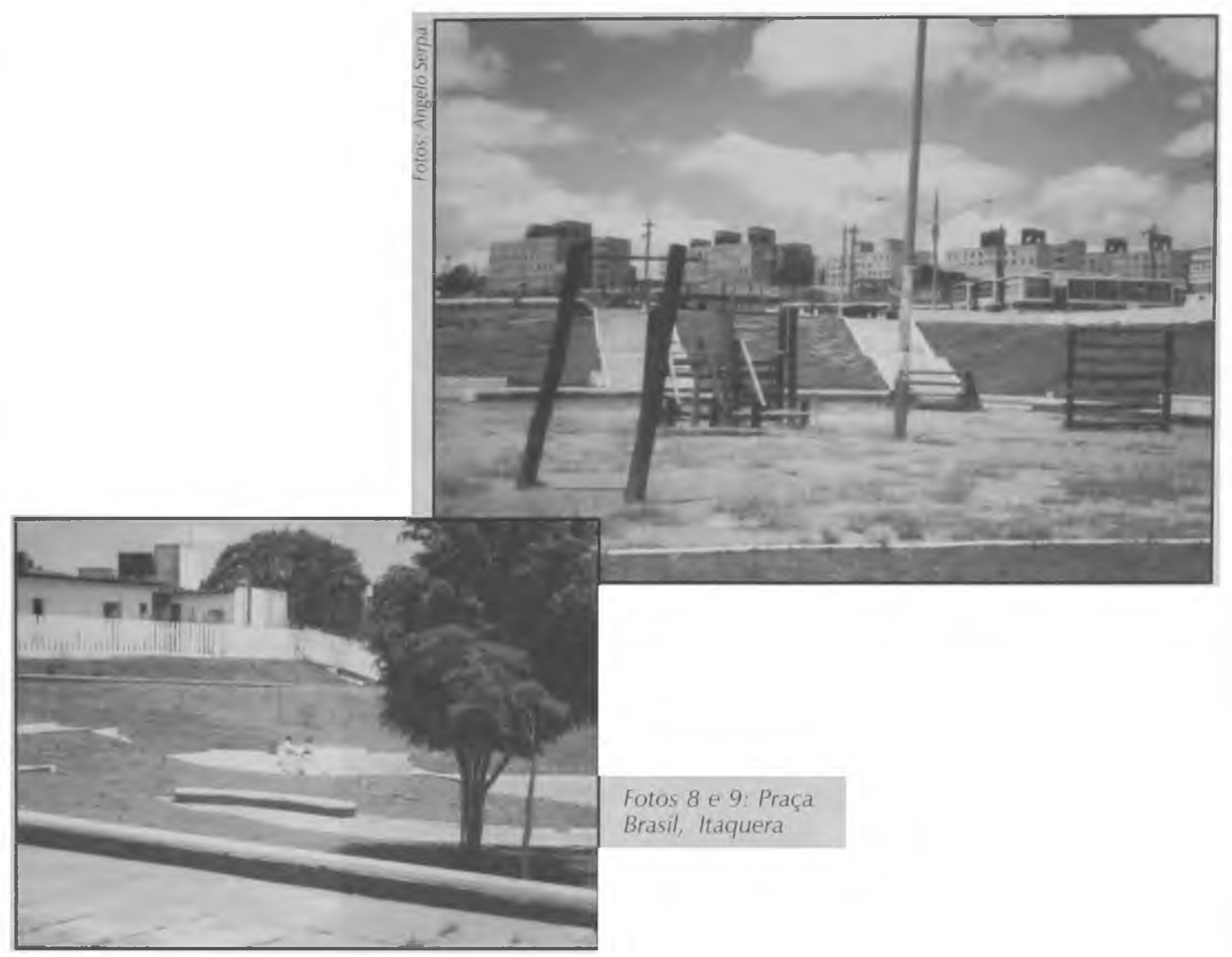

uma equipe de mão-de-obra braçal para fazer a manutenção das áreas verdes da região, mas não desta ou daquela praça (...) Isso não ocorre necessariamente dentro de um parque. Lá é possivel ter um administrador que zela por aquela área, uma equipe contratada para cuidar da manutenção e um viveiro para suprir as suas necessidades."

A arquiteta ocupa-se no momento com um projeto de revitalização do parque Raul Seixas (Fotos 10 e 11), que prevê a instalação de uma quadra de bocha, para os mais velhos, e a ampliação de um galpão existente, transformando-o em um espaço circular, com um palco em declive no centro. O espaço deverá abrigar, no futuro, exposiçōes e eventos. A idéia é diversificar o uso da área do parque, sem contudo, retirar dela o seu "ar descompromissado" 

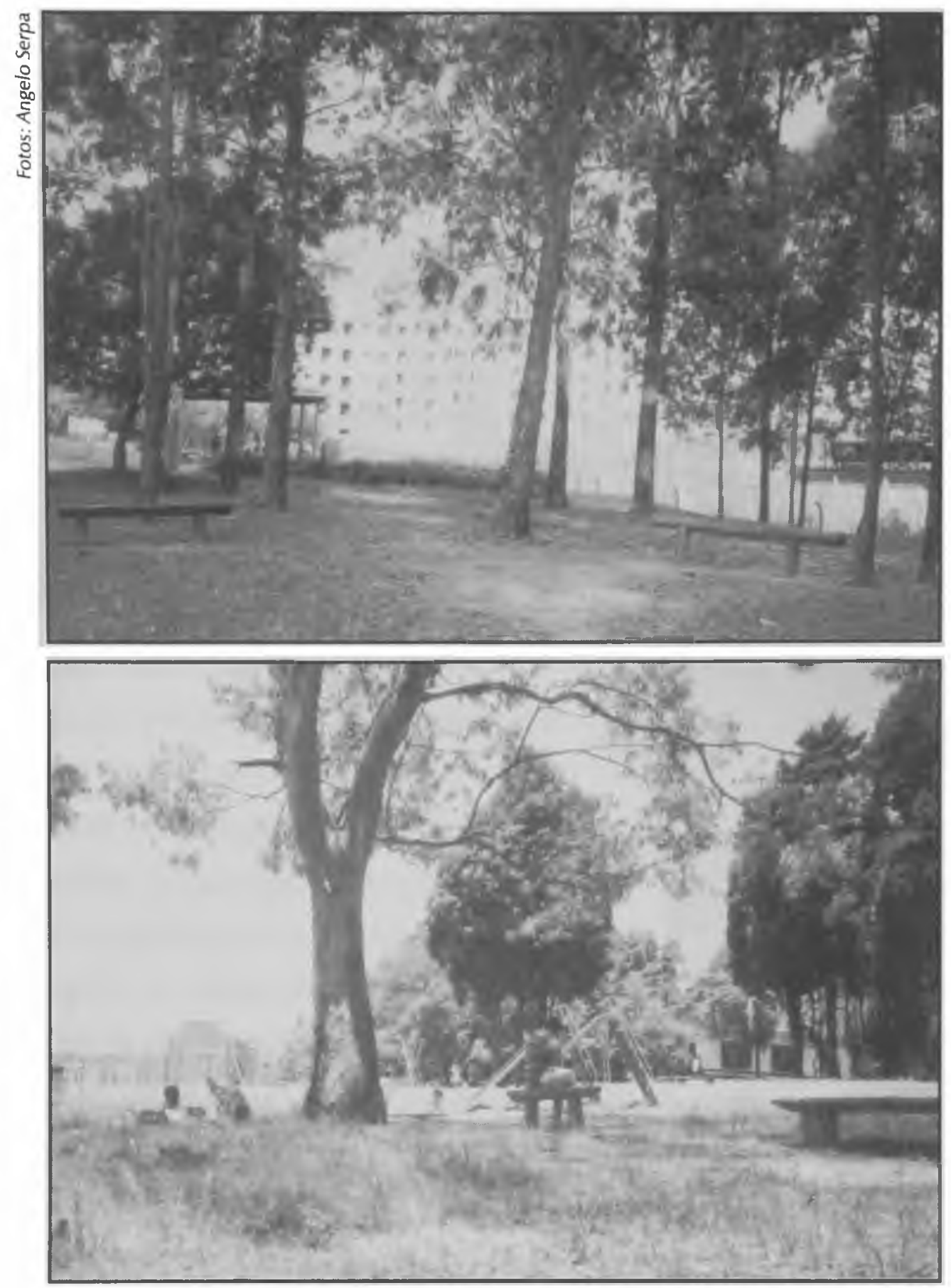

Fotos 10 e 11: O ar "descompromissado" do parque Raul Seixas

Como o parque do Carmo, o Raul Seixas leva também a marca do improviso, desde o momento da sua concepção: "Aquilo lá foi um ato de ousadia, porque a gente viu que dava para aproveitar aquela área verde vazia. Nós metemos a cara e fizemos, até meio sem apoio das instâncias centrais. Foi a regional que fez na raça", reconhece Samuel Firmo. Firmo diz que quando estava na prefeitura, 
OS ESPACOOS LIVRES DE EDIFICAÇĀO NAS

PERIFERIAS URBANAS UM DIACNÓSTICO

PRELIMINAR EM SÁO PAULO E SALVADOR

o pessoal era muito festeiro: "A Secretaria Municipal de Cultura criou várias casas de cultura durante a gestão da secretária Marilena Chauí. A Casa Raul Seixas é um exemplo. Ela conta com funcionários próprios e seleciona monitores da própria comunidade"

Isabel Lagedo, diretora da Casa de Cultura Raul Seixas, explica que a "primeira coisa que se fez foi realizar alguns encontros de formação para funcionários. Discutimos o que é cultura, o que é arte" A Casa de Cultura também realizou enquetes do tipo: "você ouve rádio?" "que programas prefere na tv?", para conhecer os gostos e interesses da comunidade. As atividades da casa incluem ainda a realização de shows e oficinas.

A diretora da Casa de Cultura reclama, no entanto, do horário de funcionamento do parque (fecha às 18 horas) e de não poder utilizar muitas vezes os equipamentos existentes na área para a realização das oficinas: "Quando se fala em meio ambiente, não se pensa nunca na praça do bairro. Nosso trabalho é com a comunidade. Quando a pessoa passa por aquela porta, ela não quer saber se aqui é o Depave ou a Secretaria de Cultura, ela só quer saber que aqui é um parque com atividades culturais. Para ela é tudo a mesma coisa."

\section{ESPAÇOS LIVRES PRIVADOS: JARDINS, PÁTIOS E ESTACIONAMENTOS}

"O ajardinamento frontal dos edifícios é um modo de tratamento do espaço, que se origina e consolida nos bairros mais ricos e de classe média alta como Higienópolis e Perdizes, espalhando-se por todo o resto da cidade, a ponto de que em São Paulo 1987 dificilmente se encontra um prédio de apartamentos, por mais distante que esteja situado, que não apresente sua parte frontal ao menos 
possuindo um modesto jardim. A consolidação deste processo é extremamente favorecida pela obrigatoriedade de recuos frontais às edificações estabelecida pelo novo código de zoneamento, que são prescritos para quase todas as áreas da cidade. Paralelamente aos recuos frontais são prescritos recuos laterais e de fundo como obrigatórios para diversas áreas, isto consolidando de vez o padrão do prédio isolado no lote."

No Conjunto Habitacional José Bonifácio, a privatização de espaços considerados no projeto original como "públicos" resulta do fato de que os mutuários cercam o lote do prédio depois de quitarem o imóvel junto à Cohab. Observa-se que as camadas menos favorecidas da população acabam assumindo o "ideal das elites":

"Os padrões de organização social dos mais ricos são reproduzidos, como todos os demais, típicos das elites sociais, de um modo reduzido, e na medida do possível, por todas as camadas sociais. A população de um conjunto habitacional, Cohab, recodifica e transforma seus espaços livres, seguindo os arquétipos das classes mais ricas, criando ao seu modo cercas, pátios, guaritas, jardins e estacionamentos."8

No Conjunto José Bonifácio, cercados os prédios de apartamentos, começa a disputa interna pela ocupação e apropriação do espaço privatizado. Ganha em regra quem grita mais alto nas assembléias dos condôminos. $O$ que prevalece são os estacionamentos com garagens (Fotos 12 e 13) e lojas (Fotos 14 e 15) de construção precária: ocupam 41\% da área total. No entanto, a percentagem de áreas ajardinadas (Fotos 16 e 17) e terrenos baldios nos espaços internos aos prédios é alta, cerca de $29 \%$.

Nos prédios com menos espaço a tendência é a redução e, em alguns casos mais radicais, a total eliminação das áreas ajardinadas no interior das edificações. Os terrenos baldios,
MACEDO, S. S.

São Paulo, paisagem e habitação verticalizada. Os espaços livres como elementos de desenho urbano. Diss. (Doutorado). São Paulo: 1987, FAUUSP, p. 64.

8 MACEDO, S. 5.

Espaços livres. Revista Paisagem e Ambiente Ensaios, v. 7, FAUUSP, São Paulo, p. 50. 
OS ESPACYOS LIVRES DE EDIFICAÇÄO NAS

PERIFERIAS URBANAS UM DIAGNOSTICO

PRELIMINAR EM SÄO PAULO E SALVADOR

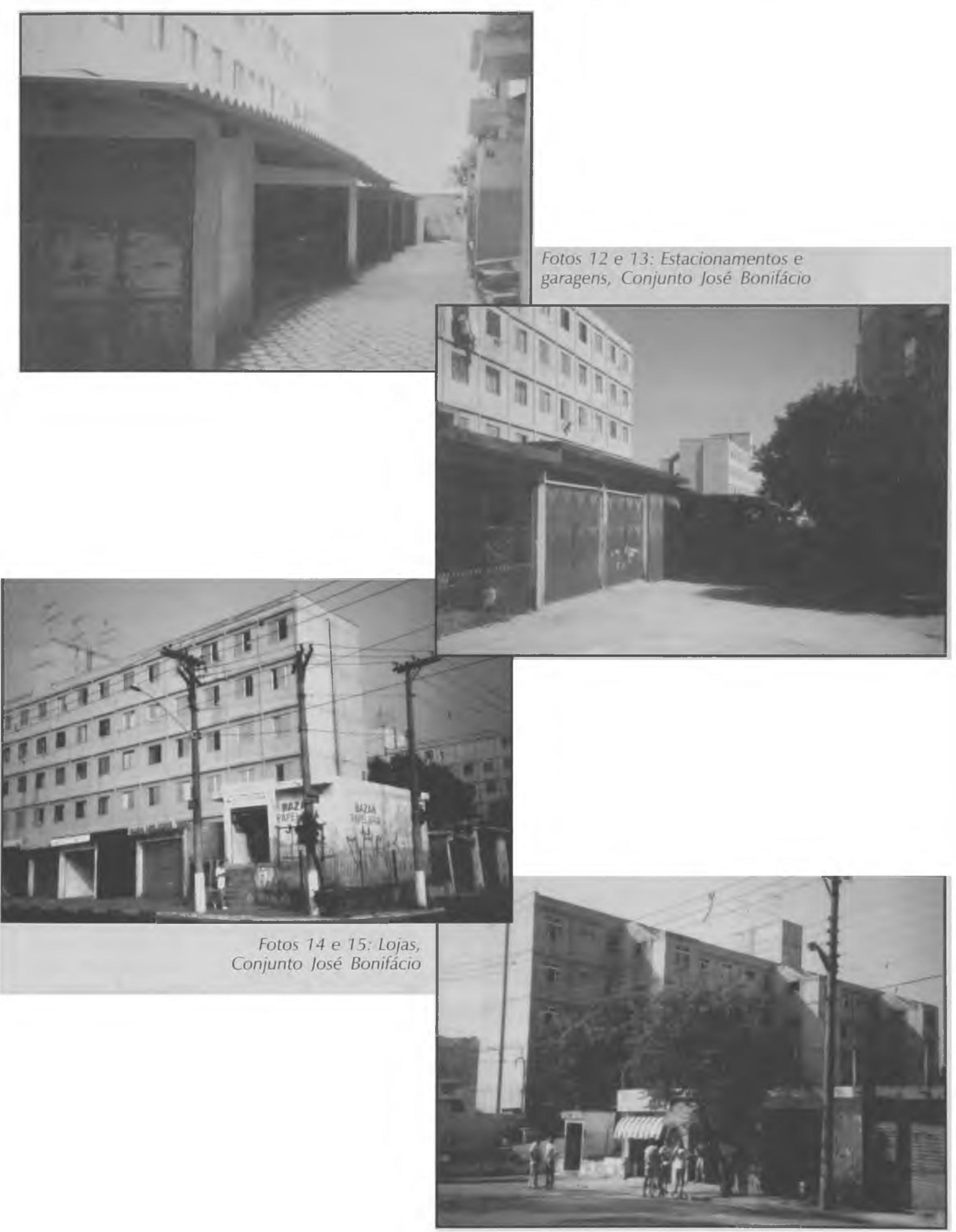




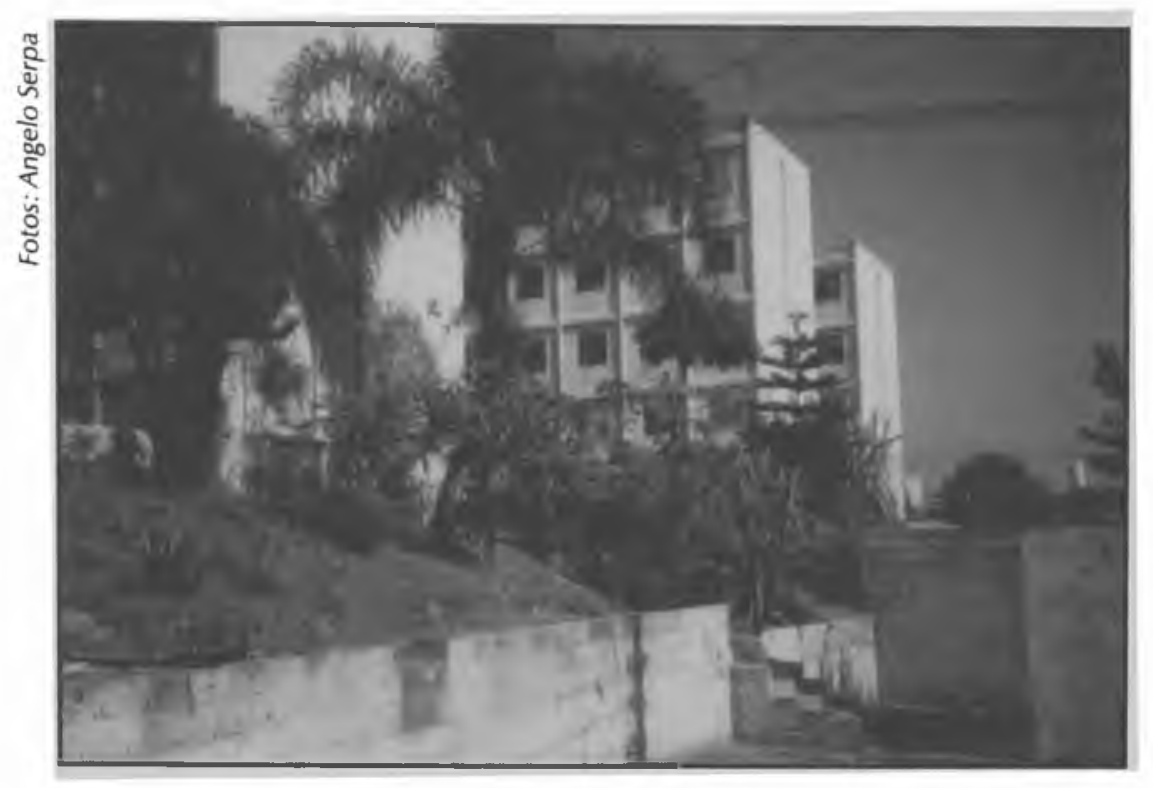

Fotos 16 e 17: A percentagem de áreas ajardinadas nos espaços internos aos prédios é alta no Conjunto José Bonifácio

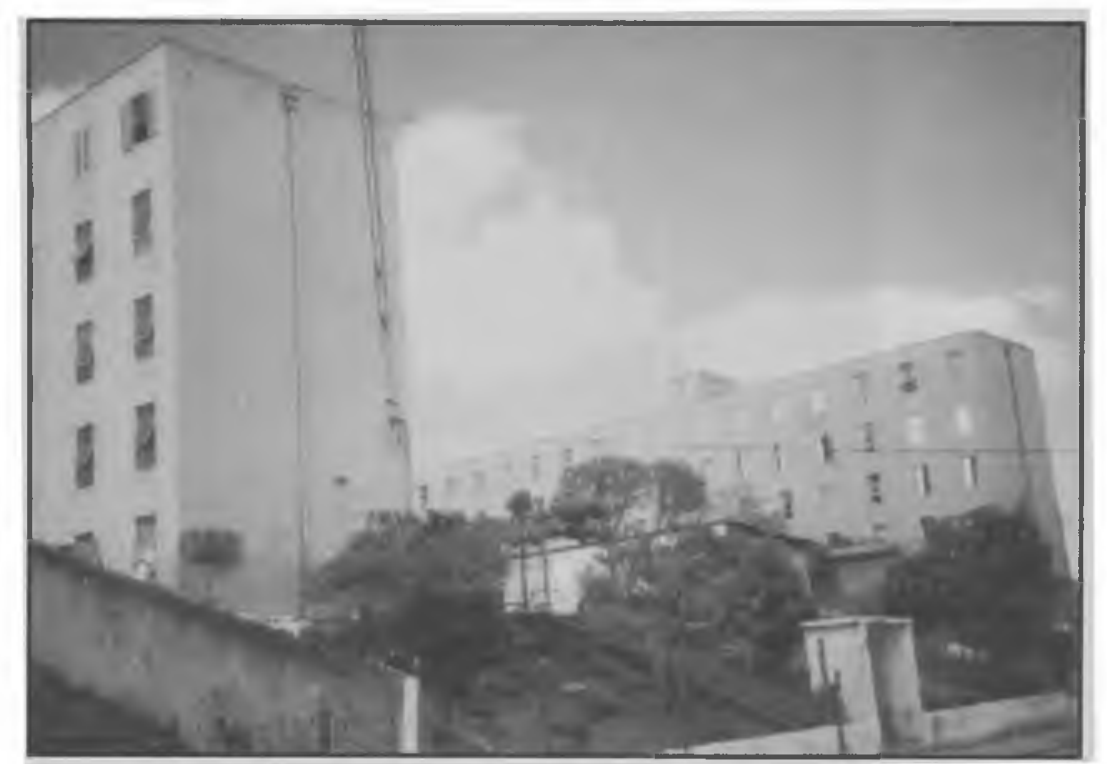

"incorporados" aos prédios vizinhos e cercados, ou apresentam declividade muito alta e são abandonados pelos moradores, ou servem como varal de roupas coletivo (Fotos 18 e 19). Nas casas padrão da Cohab (Fotos 20 e 21), cerca de $15 \%$ das unidades construídas no Conjunto José Bonifácio, os jardins frontais e os quintais desaparecem, dando lugar a garagens e a cozinhas ampliadas.

Nas casas-padrão da Cohab ninguém teve a mesma sorte que Maria Barros Ferreira, 51 anos, moradora de uma casinha "autoconstruída" 9 em Guaia-nazes, e que dispõe de um imenso quintal, onde o marido cultiva uma horta (Foto 22):
9 mancha urbana e a ocupação do espaço periférico na cidade de São Paulo são decorrentes, a partir de um dado momento histórico, da combinação entre a casa precária autoconstruída ou autogerenciada pelos moradores e o loteamento popular freqüentemente irregular ou clandestino. Essa expansão e ocupação resultaram em práticas urbanísticas peculiares, que configuraram um desenho urbano característico ao processo de urbanizaçāo do município" (Grostein, M. D. Uma cidade por refazer: a periferia paulistana. In: Revista USP, Dossiê Cidades, Mar/Ab e Maio/1990, p. 35). 
OS ESPAÇOS LIVRES DE EDIFICAÇÃO NAS

PERIFERIAS URBANAS UM DIACNÓSTICO

PRELIMINAR EM SÃO PAULO E SALVADOR

"Meu marido foi quem construiu a casa com a ajuda dos meninos, que agora estão casados. Eu gosto de planta, eu não tenho é tempo para cuidar Meu marido é aposentado, tá por aí, pelos bares. Quando está em casa gosta de cuidar das plantas."

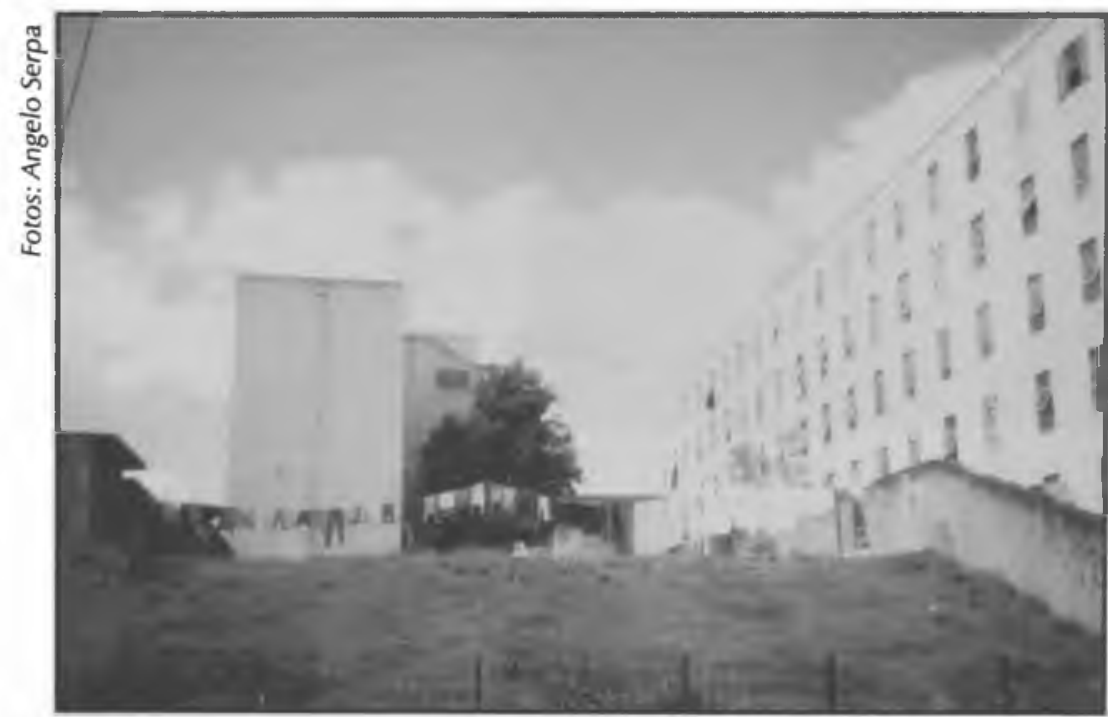

Fotos 18 e 19: Terreno baldio,

Conjunto José Bonifácio
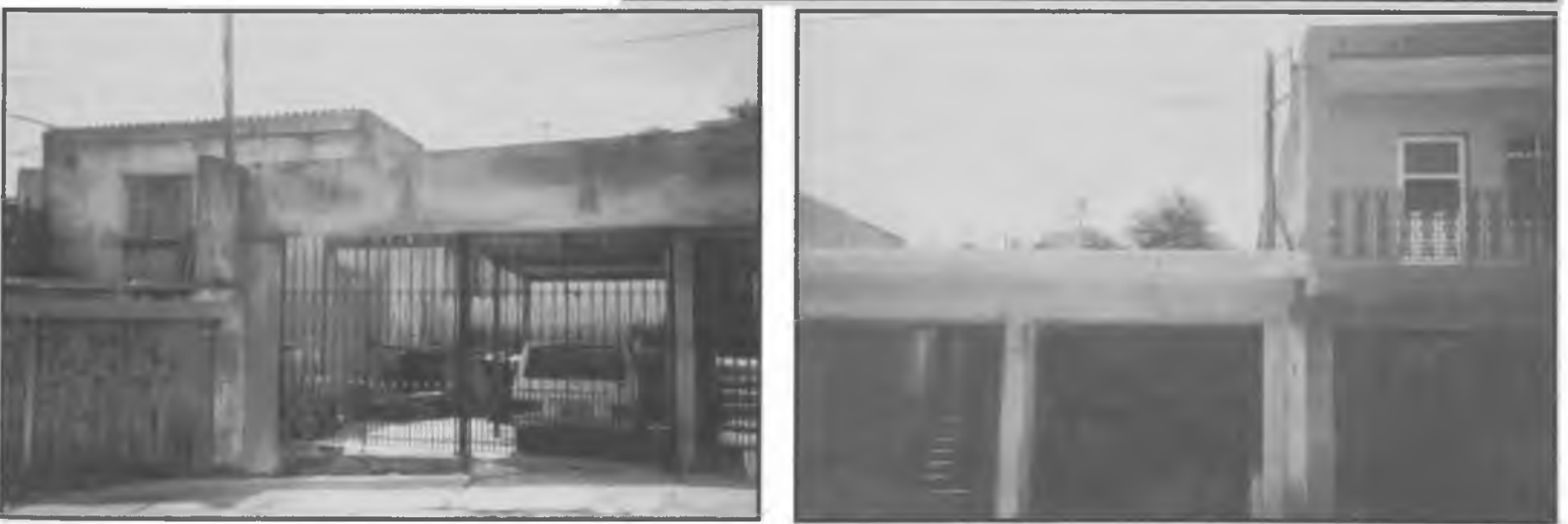

Fotos 20 e 21: As casas padrão da Cohab 


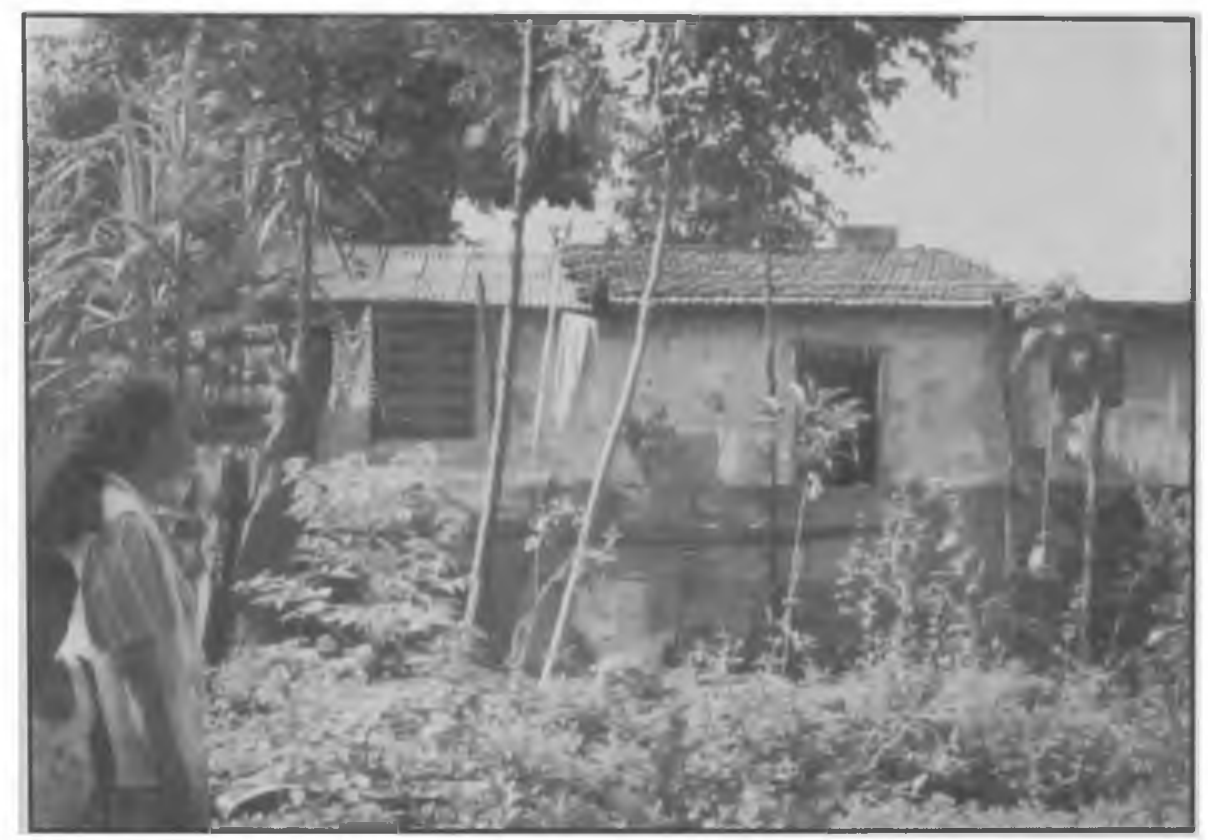

Foto 22: "Eu gosto de planta, eu não tenho é tempo para cuidar"

\section{O CASO DE PLATAFORMA E CAJAZEIRAS EM SALVADOR}

Com cerca de 58 mil habitantes, Plataforma é um bairro centenário, de origem operária ${ }^{10}$ Com a decadência do transporte ferroviário e a desativação da linha de barcos que encurtava a travessia da Baía de Todos os Santos para a Ribeira e o centro da cidade, o bairro sofre com o isolamento e o descaso dos órgãos públicos. Erguidos pela Urbis (Habitação e Urbanização da Bahia) na década de 80 , os conjuntos habitacionais populares de Cajazeiras equivalem em dimensão e população ao bairro de Plataforma ${ }^{11}$, mas apresentam características bastante diferentes quanto ao desenho urbano. Em comum, os dois sistemas possuem a topografia acidentada, o isolamento do centro da cidade e a forte descontinuidade entre os diferentes setores.

\section{OS ESPAÇOS LIVRES PÚBLICOS}

Plataforma apresenta uma maior percentagem de espaços abertos sobre a área total (18\%) que os conjuntos Cajazeiras $\mathrm{X}$ e XI (10,5\% e 13\%, respectivamente). Embora com caracterís-
10 A velha fábrica de tecidos São Brás, junto ao terminal marítimo de Plataforma, guarda, por trás da sua fachada, mais de cem anos da história do bairro: são quase 10 mil metros quadrados de edificaçōes em estilo inglês, típicas das tecelagens industriais do início do século. A tecelagem foi fundada em 1875 e sofreu sua primeira reforma em 1908. O bairro cresceu a partir da fábrica, especialmente o comércio local. É difícil encontrar em Plataforma quem não trabalhou ou tem pelo menos um parente na família que era empregado da indústria de tecidos. 
OS ESPACOS LIVRES DE EDIFICAÇĀO NAS

PERIFERIAS URBANAS UM DIACNÓSTICO

PRELIMINAR EM SÃO PAULO E SALVADOR

11 Os conjuntos habitacionais em Cajazeiras foram construídos em quatro etapas, de acordo com os dados fornecidos pela Urbis:

Primeira etapa (ano de conclusāo: 1978): Cajazeiras IV (641 unidades) e V (1001 unidades).

Segunda etapa (ano de conclusāo: 1979):

Cajazeiras VII (708

unidades).

Terceira etapa (ano de conclusão: 1983): Cajazeiras VI (1254 unidades), VIII (1476 unidades), X (1775 unidades) e XI (2400 unidades).

Quarta etapa (ano de conclusão: 1985): Cajazeiras III (605 unidades). ticas morfológicas distintas, os bairros apresentam um relevo bastante acidentado, que se constitui em um fator determinante na ocupação dos espaços disponíveis. A forte descontinuidade da massa construída é definida, portanto, por barreiras naturais (diferenças de nível), intransponíveis para as pessoas em sua movimentação normal sobre o solo. Em Cajazeiras, os conjuntos de prédios, casas e sobrados estão distribuídos como "ilhas", contornando morros e áreas mais inclinadas (Foto 23). Em Plataforma, as áreas mais densamente ocupadas são os fundos de vale e os poucos platôs naturais existentes (Foto 24).

Os espaços livres públicos possuem dimensões médias menores no bairro de Plataforma que nos conjuntos Caja-zeiras X e XI (tamanho médio de $296 \mathrm{~m}^{2}$ contra $432 \mathrm{~m}^{2}$ em Cajazeiras X e $590 \mathrm{~m}^{2}$ em Cajazeiras XI). Mesmo entre os conjuntos habitacionais analisados existem diferenças de organização e concepção da massa construída bem como do sistema de espaços abertos. Em Cajazeiras X, há um dimensionamento mais humano dos espaços livres de edificação que em Cajazeiras XI, devido talvez à inexistência, no primeiro caso, de prédios mais altos e à predominância de casas e sobrados (Foto 25).

Em Plataforma há uma maior distribuição dos passantes/ usuários nas diversas unidades do sistema de espaços abertos, enquanto que nos conjuntos habitacionais há uma maior "canalização" de percursos, com a circulação dos usuários concentrada nas vias centrais, ao longo das quais se distribuem perpendicularmente às ruas secundárias, caracterizadas na sua maior parte como becos sem saída.

Em Plataforma há isolamento não só em relação ao exterior mas também um isolamento intrabairro, com a concentração de passantes/usuários nas vias e espaços centrais (praça São Brás 
e adjacências - Foto 26) e nas proximidades do terminal de ônibus (Largo do Tanque - Foto 27). A falta de planejamento e o grande número de construções ilegais no bairro fecha acessos e impede a circulação dos usuários, isolando a região do loteamento orla.
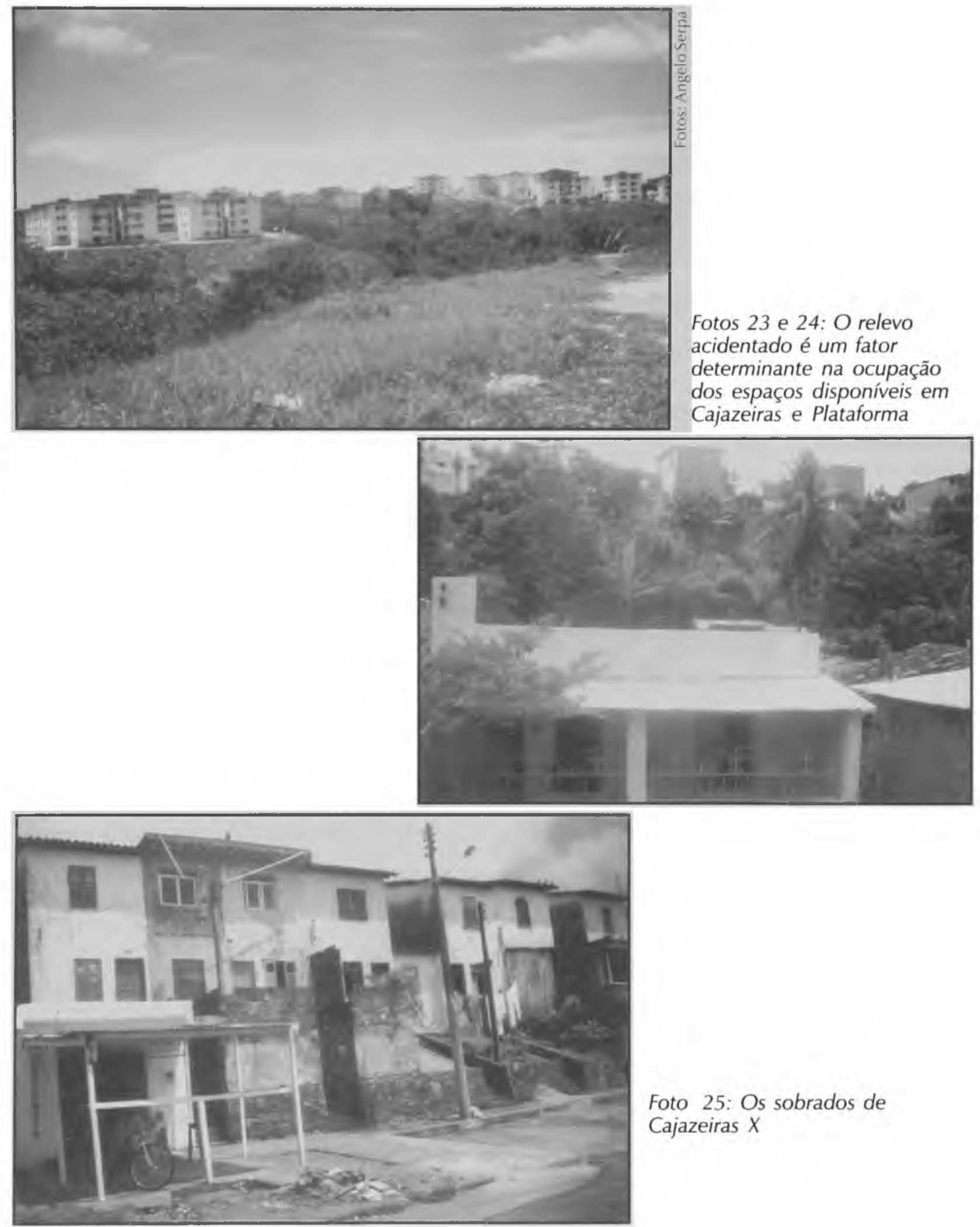

Foto 25: Os sobrados de Cajazeiras $X$ 

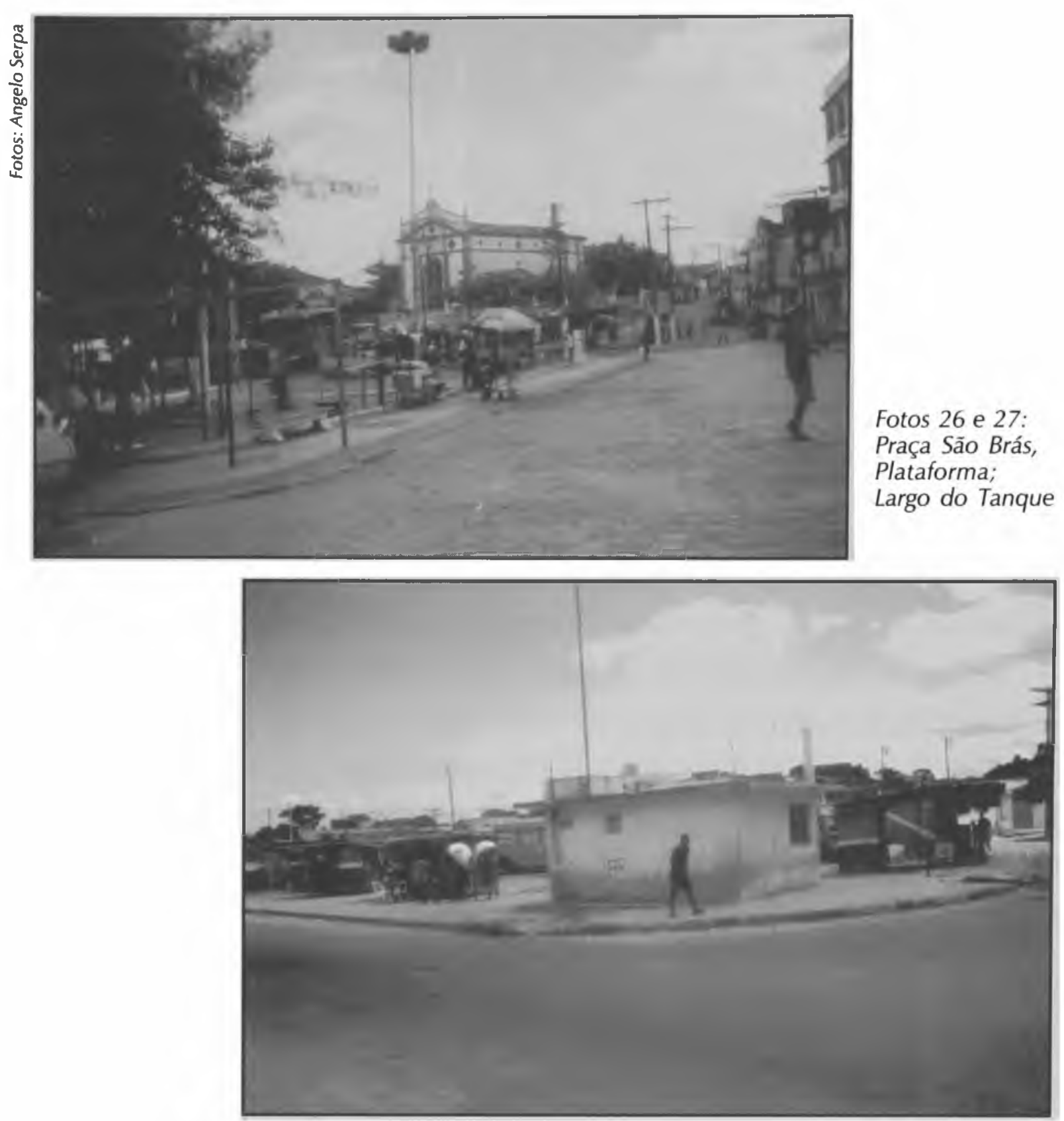

\section{APROPRIAÇÃO SOCIAL DOS ESPAÇOS LIVRES PÚBLICOS}

Em Plataforma, a alta densidade populacional, a ocupação desordenada do solo e a predominância de habitações autoconstruídas restringem a apropriação dos espaços livres de edificação existentes. A maioria das ruas não possui calçamento (Fotos 28 e 29), largos e praças são subdimensionados e pouco utilizados pelos moradores.

Exceção à regra são a praça São Brás (3.304 m² de área), localizada no "miolo" do bairro e para onde convergem as 

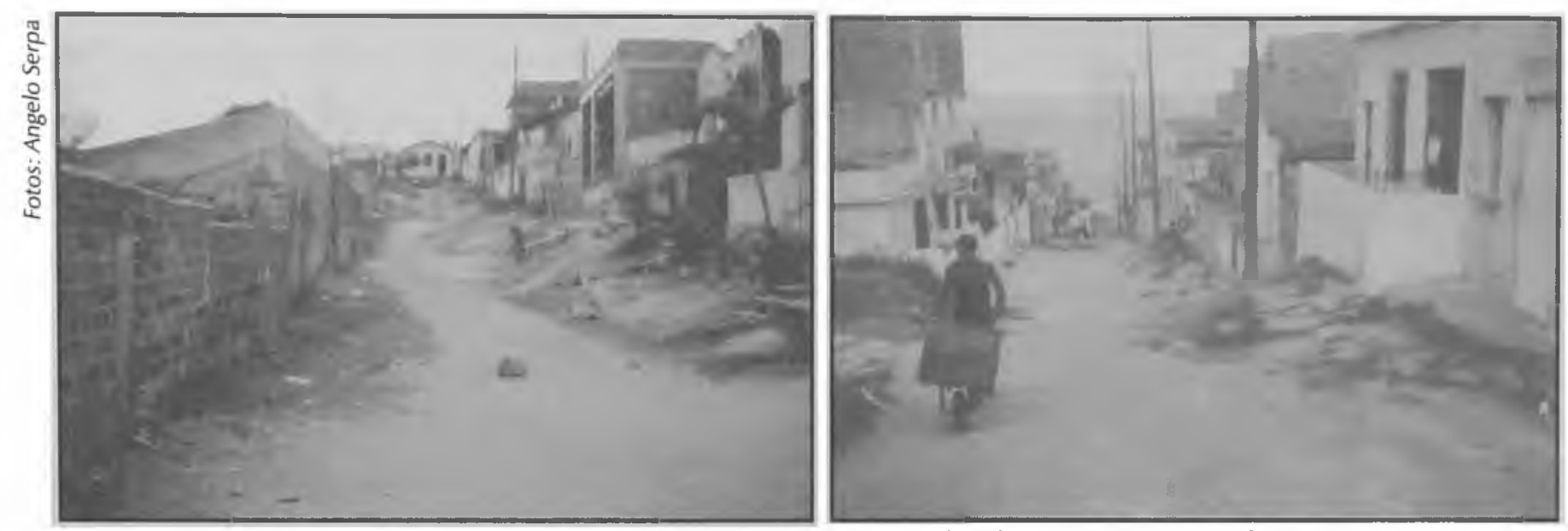

Fotos 28 e 29: A falta de calçamento é comum em Plataforma (Fotos: Angelo Serpa)

ruas principais, e o largo do Tanque $\left(3.512 \mathrm{~m}^{2}\right.$ de área), onde está situado o terminal de ônibus. Nos dois casos verifica-se uma alta concentração de barracas para venda de comidas e bebidas alcoólicas, além da existência de um comércio incipiente. Na praça São Brás encontram-se padarias, armarinhos, lojas de móveis, depósito de bebidas, além da associação de moradores ${ }^{12}$, do Cine-Teatro Plataforma (fechado há alguns anos) e da Igreja São Brás, referencial arquitetônico do bairro.

Algumas praças e largos de importância local podem ser encontrados no loteamento Orla (pequenos espaços verdes, utilizados principalmente pelos moradores das casas vizinhas como extensão da casa - Fotos 30 e 31), no Mabaço de Baixo (um pequeno largo, onde se localiza uma das igrejas evangélicas do bairro - Foto 32) e no Baixo São João (também um largo pequeno, onde se localiza um ponto de ônibus, utilizado principalmente como "local de passagem" - Foto 33). Alguns campos de futebol, distribuídos próximos ao largo do Tanque e no Baixo São João (Foto 34) completam a "oferta" de espaços livres existentes em Plataforma.

Nos conjuntos habitacionais de Cajazeiras, os espaços públicos são superdimensionados e, na maior parte dos casos, pouco utilizados (têm "vocação" de lugar de passagem). Em
12 Organizados em uma associação (AMPLA), os moradores de Plataforma vêm lutando, desde 1978, pela melhoria das escolas locais, abertura de novas escolas e creches. Sem ajuda dos poderes públicos fundaram eles mesmos, em 1979, a Escolinha Comunitária Chapéuzinho Vermelho e, em 1982, a creche comunitária. O prédio, onde hoje funcionam a creche, a escola e a sede da associação de moradores foi construído através de mutirōes e supre, dentro das possibilidades de uma instituição criada e mantida por uma associaçāo de moradores, as necessidades locais em termos de atendimento às crianças com idade variável de 3 a 6 anos. A creche-escola se 
OS ESPACOS LIVRES DE EDIFICACÃO NAS

PERIFERIAS URBANAS UM DIAGNÓSTICO

PRELIMINAR EM SÄO PAULO E SALVADOR

mantém graças ao trabalho voluntário das mulheres da comunidade e atende a cerca de 110 crianças em regime de tempo integral. Além disso, a associação dispōe de um núcleo de costura e tecelagem, marcenaria, serralheria e padaria comunitária.
Cajazeiras XI uma sucessão de estacionamentos pavimentados, dispostos ao longo das vias centrais, são utilizados pelos moradores como quadras improvisadas de vôlei (Foto 35) e futebol de salão e, em alguns casos, transformados em pequenas praças pelos próprios moradores do entorno. Em Cajazeiras $X$ uma praça de porte médio é intensivamente usada pelos moradores das casas mais próximas (Foto 36).

Ao contrário do Conjunto José Bonifácio em Itaquera, São Paulo, não se verifica a privatização dos espaços livres entre os prédios pelos moradores. Com raras exceções, não há muros isolando o prédio no lote, o que torna possível o acesso a estes espaços não só para os moradores dos edifícios, mas também para os passantes e visitantes.

Os espaços livres localizados na frente dos prédios adquirem em alguns casos feições de pequenas praças de importância local (com plantio de árvores e utilização de bancos), bastante usadas pelos moradores do entorno (Fotos 37 e 38). Os espaços mais reservados são utilizados para varal de roupas (Foto 39), estacionamento (Foto 40), plantio de hortícolas, temperos e plantas ornamentais ou área de estar (com bancos improvisados de madeira).

\section{ENTRE O PÚBLICO E O PRIVADO}

O homem moderno é um homem só. Prisioneiros da cultura do ego, vivemos em uma sociedade onde o indivíduo se sobrepõe ao coletivo. Para que os conflitos sejam minimizados e para que se preserve uma certa "soberania" sob condições de proximidade física, fazemos questão de manter alguma distância psicológica, mesmo nas relações mais íntimas. Nossas relações de vizinhança são condicionadas de uma forma determinante pela densidade populacional do local que habitamos, pelo nível econômico 


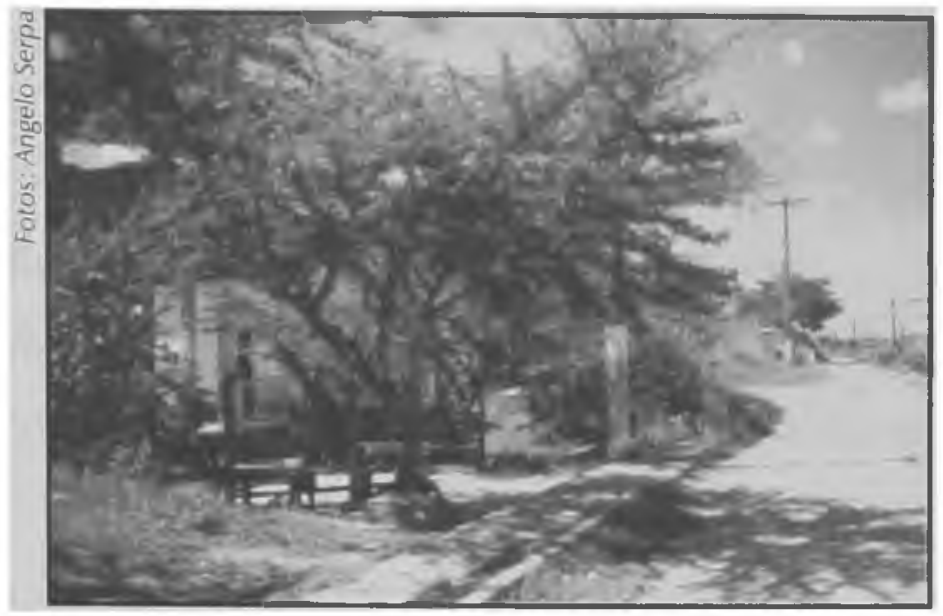

Fotos 30 e 31 Loteamento Orla, Plataforma
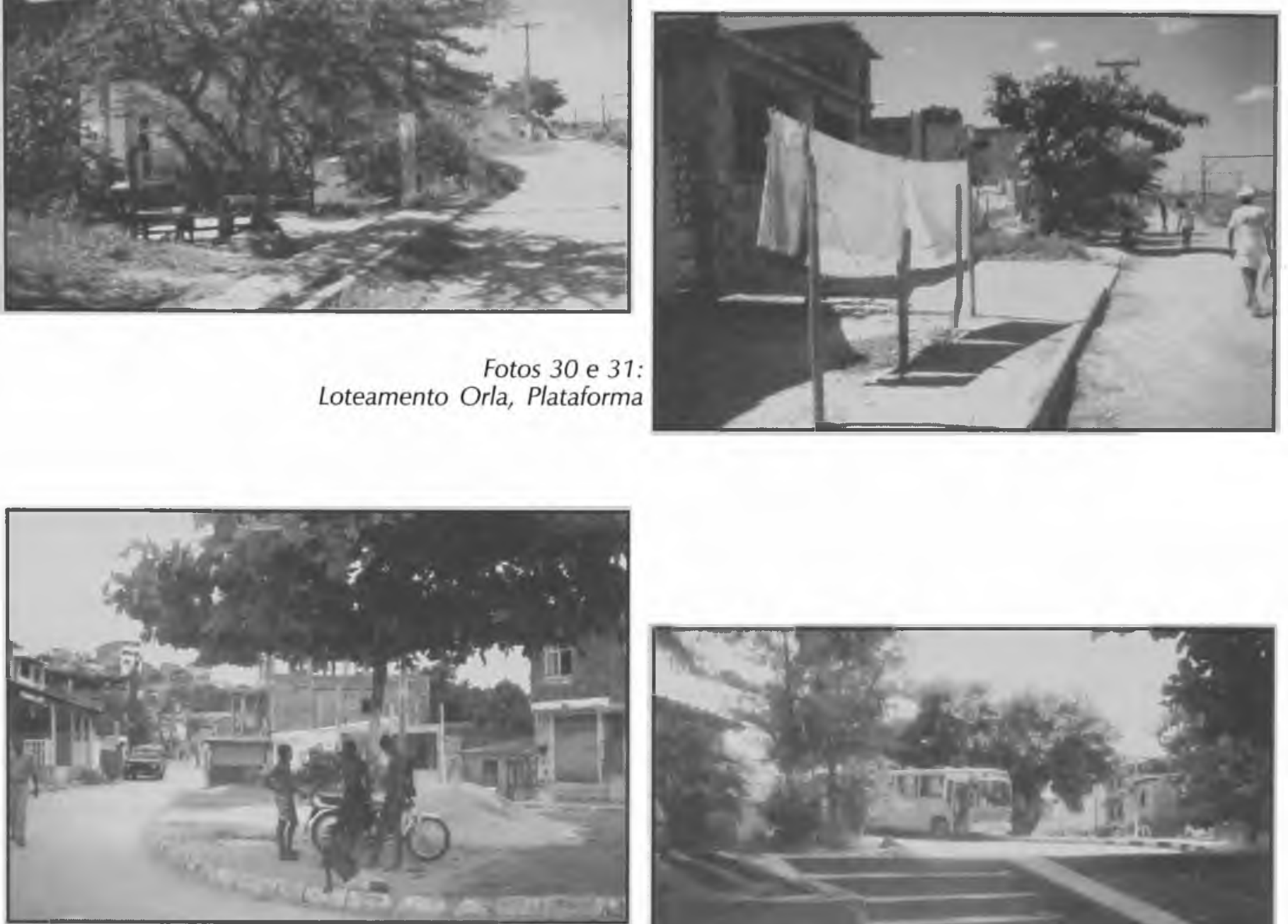

Foto 32: Largo no Mabaço de Baixo, Plataforma
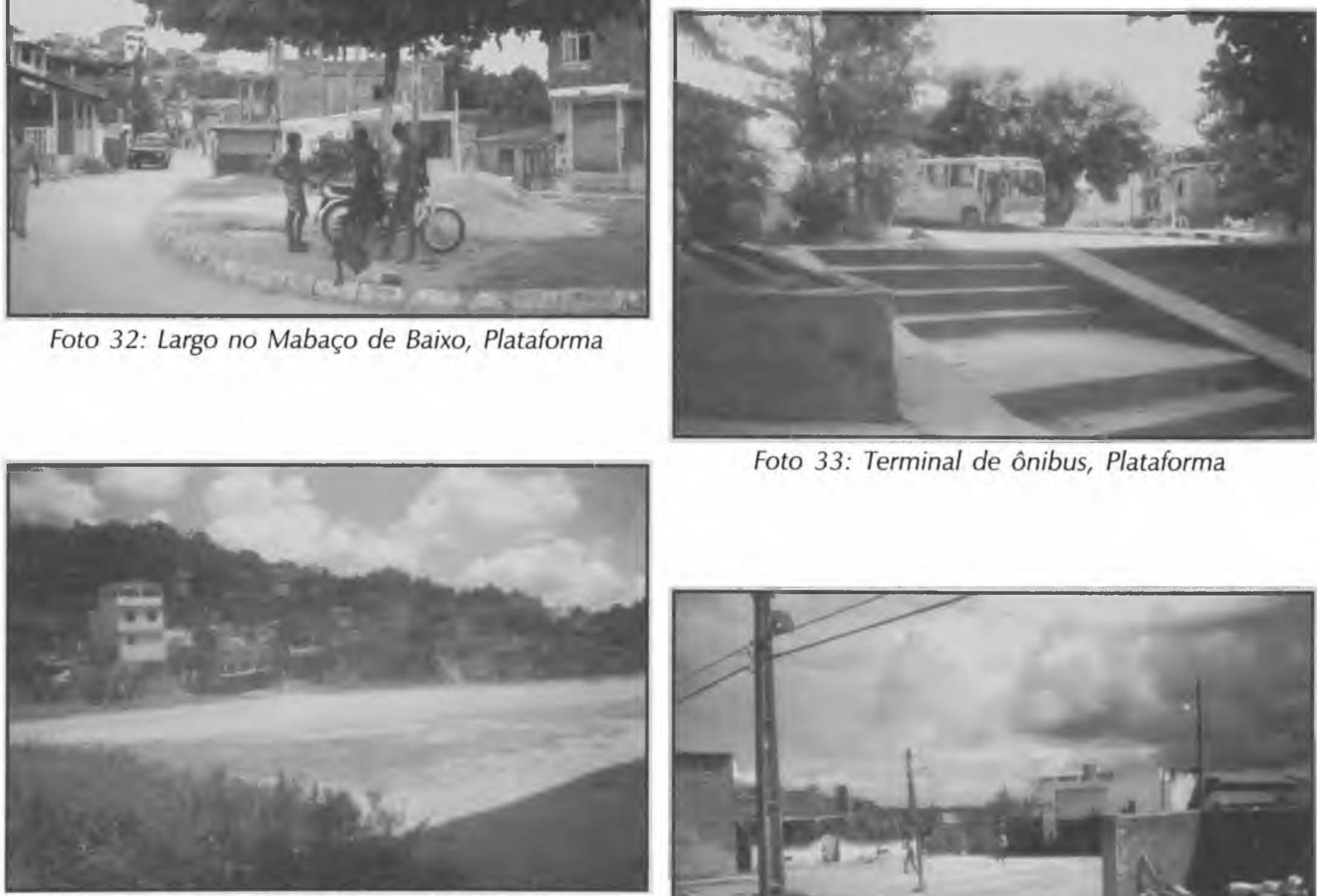

Foto 33: Terminal de ônibus, Plataforma

Foto 34: Campo de futebol no Baixo São João, Plataforma

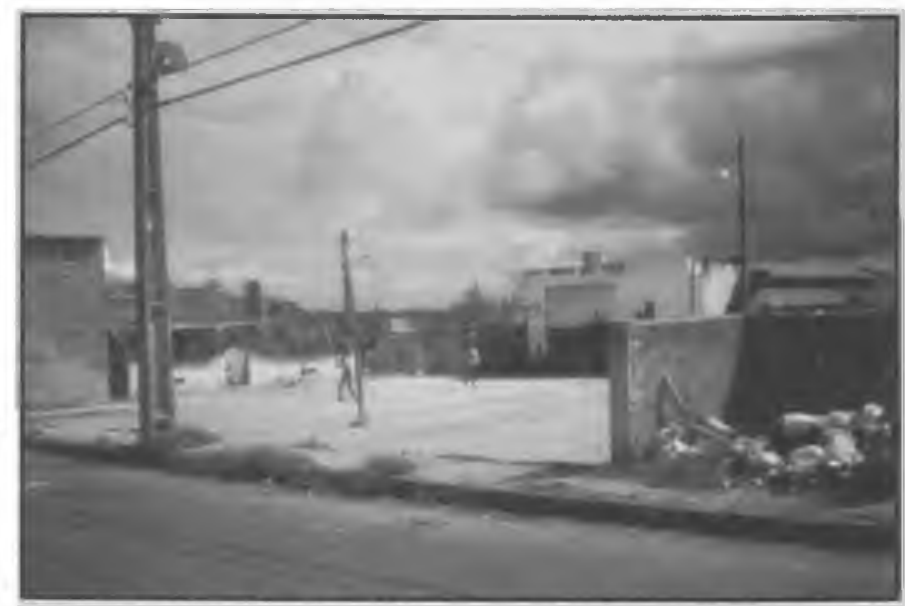

Foto 35: Quadra de vôlei improvisada em Cajazeiras XI 
OS ESPAÇOS LIVRES DE E IFICAÇÃO NAS

PERIFERIAS URBANASUM DIACNOSTICO

PRELIMINAR EM SÄO PAULO E SALVADOR

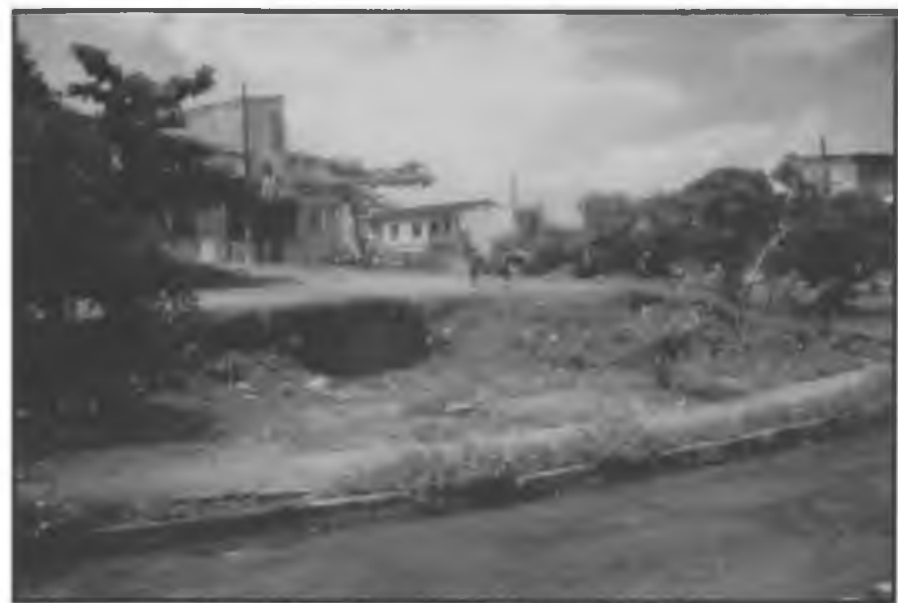

Foto 36: Praça em Cajazeiras $X$

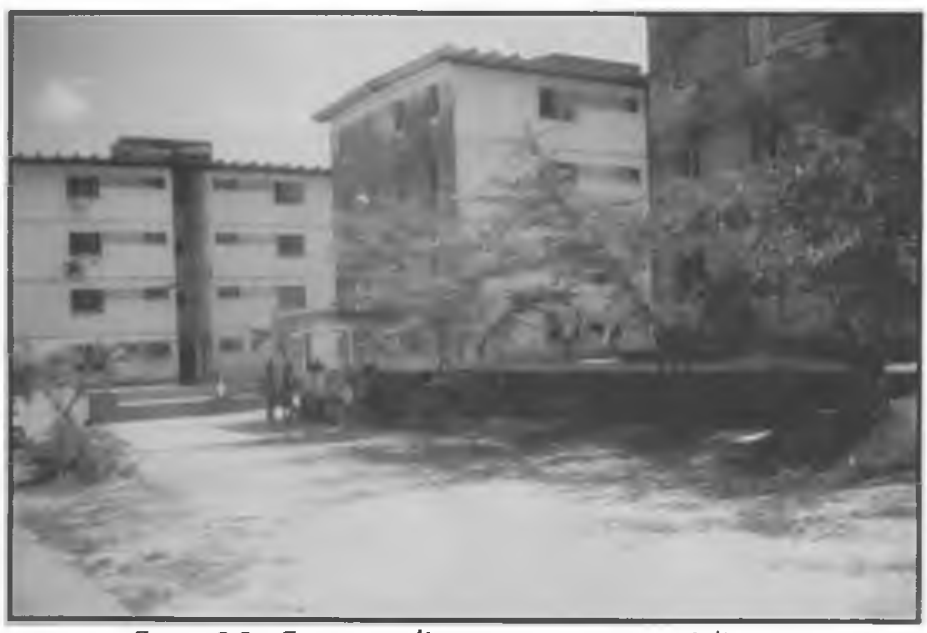

Foto 38: Espaços livres entre os prédios de Cajazeiras XI

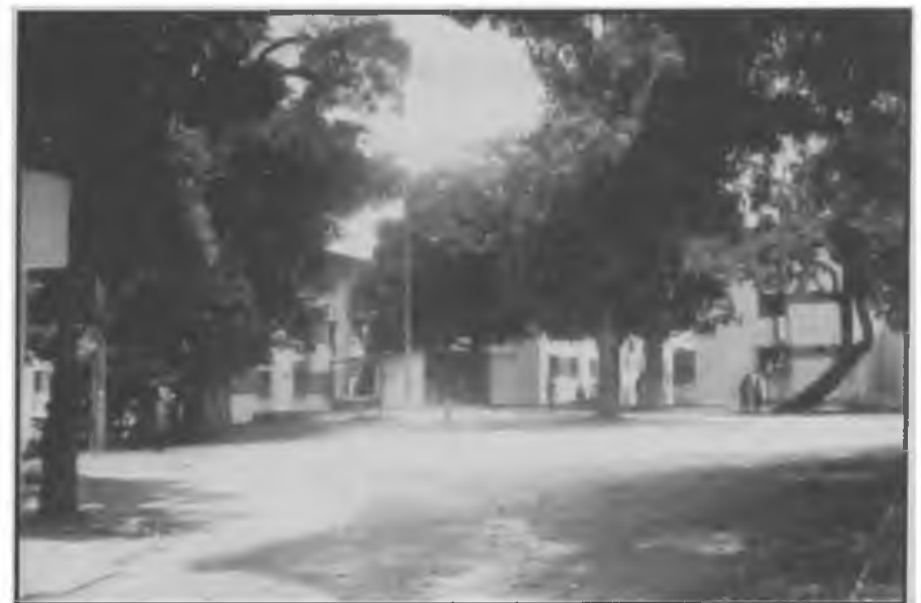

Foto 37: Espaços livres entre os prédios de Cajazeiras XI

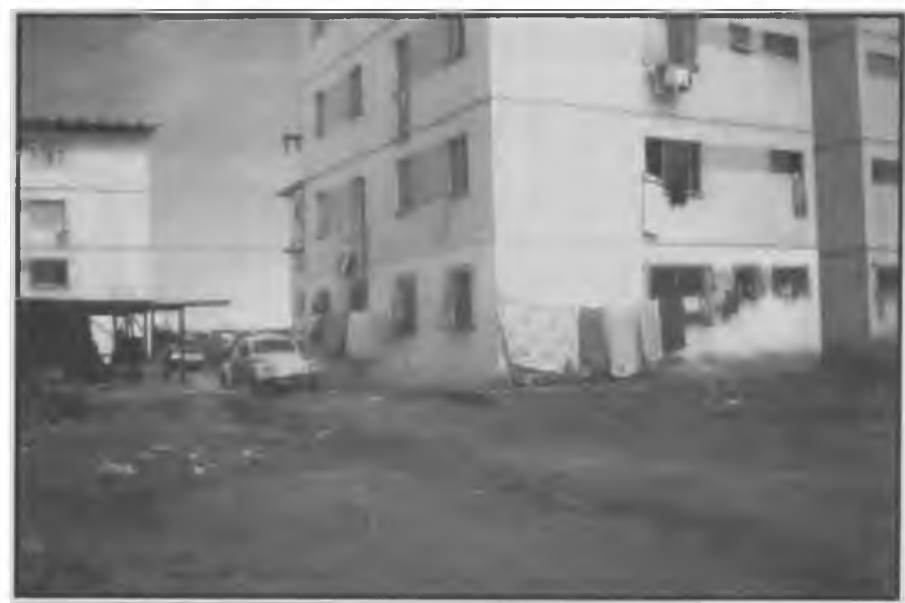

Foto 40: Estacionamento entre os prédios, Cajazeiras XI

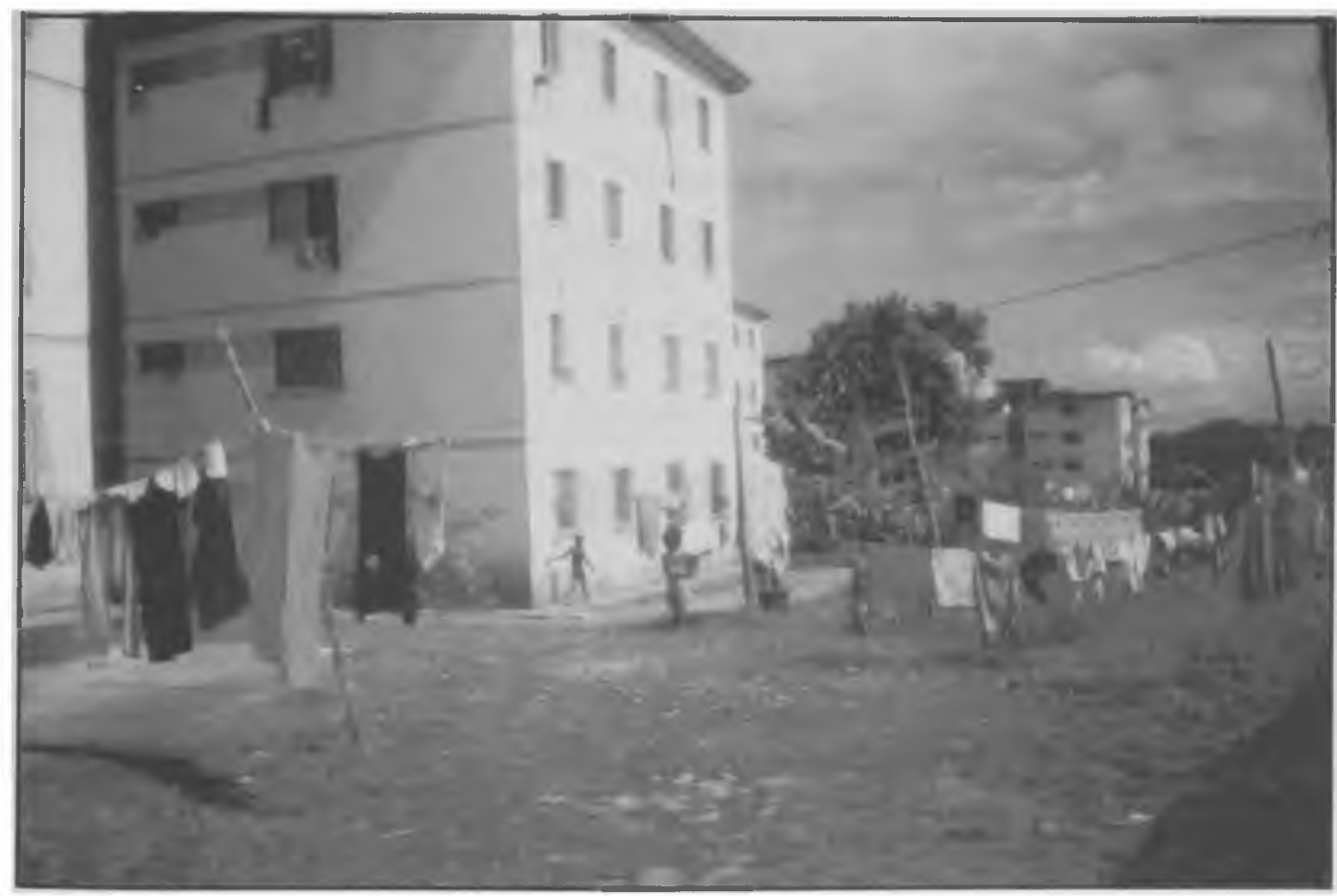

Foto 39:

Varal de roupas

em Cajazeiras XI 
e o grau de cooperação dos seus habitantes, bem como pela distância entre as unidades de habitação ${ }^{13}$ Estamos sós e gostamos de estar sós.

As relações de vizinhança na cidade contemporânea são muito determinadas ainda pelas diferenças entre classes sociais. Nos bairros operários, a limitação de oportunidades, a pobreza e o isolamento relativos, a insegurança e o medo acabam por fortalecê-las e torná-las parte fundamental da trama de relações familiares. Nos bairros de classe média, as relações entre vizinhos são mais seletivas e pessoais, já que o maior poder aquisitivo faz diminuir a necessidade de ajuda mútua e aumentar a necessidade individual de espaço ${ }^{14}$

A privatização dos espaços livres de uso coletivo é, no entanto, um problema que atinge as cidades como um todo, sem distinção de classes. Na sua coluna diária em $A \operatorname{Tarde}^{15} \mathrm{o}$ jornalista Samuel Celestino anuncia, por exemplo, a preocupação da prefeitura de Salvador com o combate às chamadas "invasões de colarinho branco" São condomínios que ocupam terrenos com playgrounds e áreas de lazer (de uso restrito aos moradores dos prédios), são escolas e faculdades particulares que levam seus muros alguns metros à frente para abrigar mais laboratórios e salas de aula (de uso restrito aos estudantes daquelas instituições). O outro lado da moeda mostra uma Salvador favelizada, sitiada por 357 assentamentos espontâneos, de acordo com um estudo recente da Conder ${ }^{16}$

A privatização de ruas e acessos restringe o movimento de passantes, canaliza percursos e provoca a desertificação de muitas áreas urbanas periféricas. O arquiteto Bill Hillier ${ }^{17}$, um teórico inglês do desenho urbano, chama atenção para o fato de que os passantes representam um importante papel no controle e fiscalização do espaço. Suas pesquisas mostraram que os passantes controlam o espaço e os habi-
13 KELLER, S. (1979), cit. por RIGATTI, D. Apropriação social do espaço público. Um estudo comparativo. Revista Paisagem e Ambiente-Ensaios, v. 7, FAUUSP, São Paulo, 1994, p. 149-150.

14 Idem, Ibidem.

15 A Tarde é o jornal de maior circulação no Norte-Nordeste (100.000 leitores), editado em SalvadorBahia.

16 Companhia de Desenvolvimento da Regiāo Metropolitana de Salvador.

7 HILLIER, B. \& HANSON, J. The social logic of space. Cambridge: Cambridge University Press, 1984. 
tantes, por sua vez, os passantes. Assim, uma fração do espaço poderia ser automaticamente fiscalizada e controlada, sem o uso de vigias, porteiros ou equipamentos eletrônicos. Com o confinamento dos moradores nos prédios dos conjuntos habitacionais populares, agrava-se a questão das drogas e aumenta a violência urbana; decreta-se (muitas vezes de modo irreversível) a morte dos espaços livres de uso coletivo.

Nas ruas das áreas centrais, os pedestres cedem seu lugar nas calçadas aos automóveis e camelôs (Fotos 41 e 42). Em uma

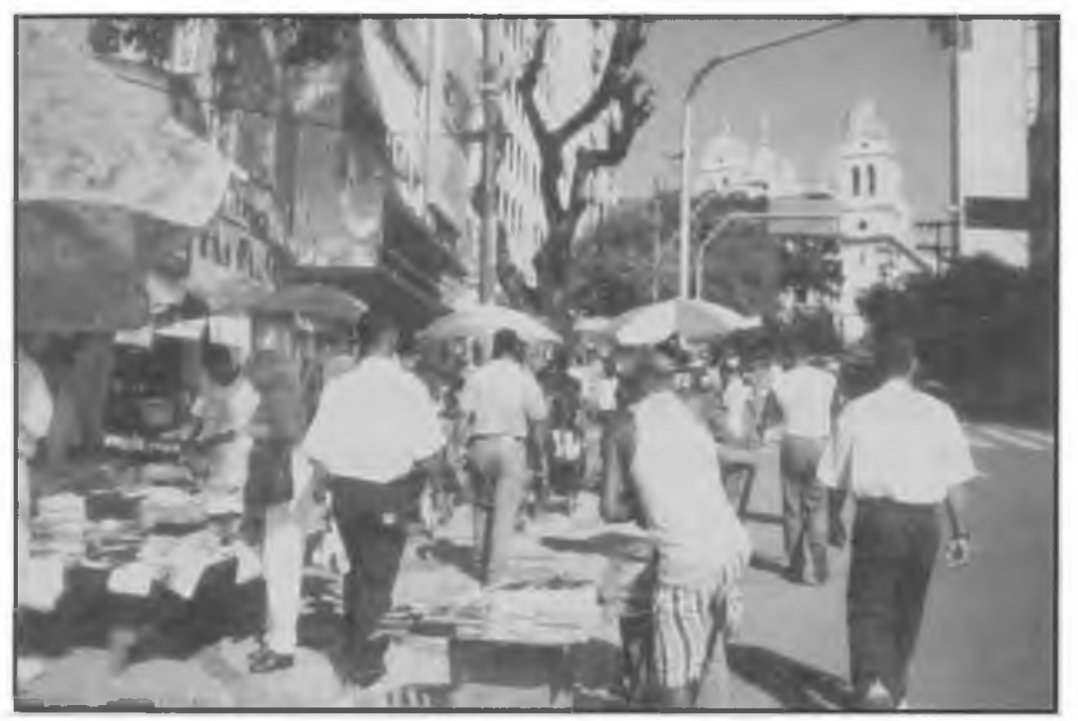
cidade como Salvador, com ruas estreitas e tortuosas, parece não haver mais espaço para o passeio a pé. Quem se arrisca a fazê-lo deve disputar o asfalto com os carros, ambulantes e caminhões, que também transitam livremente pelo centro da cidade (não há horários específicos para carga e descarga).

Fotos 41 e 42: Centro de Salvador tomado por camelôs.

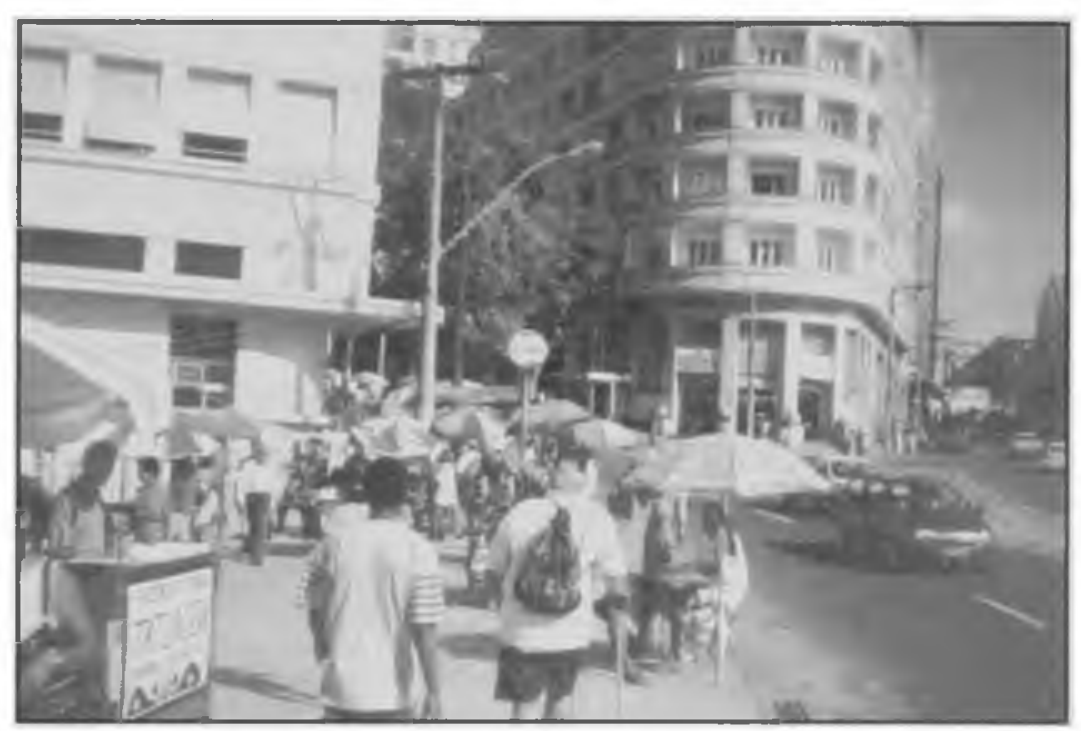


Todos estes exemplos nos mostram que a crise da modernidade é uma crise nos domínios público e privado. A erosão do equilíbrio entre a vida pública e a vida privada destrói o pilar que sustentava a sociedade nos primórdios do capitalismo $^{18}$ Caminhamos para a consagração do individualismo como modo de vida ideal, em detrimento de um coletivo cada vez mais decadente. Estamos sós e gostamos de estar sós (até quando?).

\section{BIBLIOGRAFIA}

GOULART, P. C. A. Pracidade. Trabalho de Graduação Interdisciplinar, São Paulo: FAUUSP

GROSTEIN, M. D. Uma cidade por refazer: a periferia paulistana. In: Revista USP, Dossiê Cidades, mar./abr. e Maio, São Paulo, 1990.

HILLIER, B., HANSON, J. The social logic of space. Cambridge: Cambridge University Press, 1984.

KELLER, S. El vecindário urbano: una perspectiva sociológica. 2. ed. México: Siglo XXI ed., 1979, cit. por RICATTI, D. Apropriação social do espaço público. Um estudo comparativo. Revista Paisagem e Ambiente-Ensaios, v. 7, São Paulo: FAUUSP, 1995.

KLIASS, R. G. Parques urbanos de São Paulo. São Paulo: Pini Editora, 1994.

MACEDO, S. S. Sāo Paulo, paisagem e habitação verticalizada. Os espaços livres como elementos de desenho urbano. São Paulo, 1987. Diss. (Doutorado) Faculdade de Arquitetura e Urbanismo - Universidade de São Paulo.

MACEDO, S. S. Espaços livres. In: Revista Paisagem e Ambiente - Ensaios, v. 7 , São Paulo: FAUUSP, 1995.

SEGAWA, H. Do amor ao público. Jardins no Brasil 1779-1911. São Paulo: FAUUSP, 1994.

SENNET, R. O declínio do homem público. São Paulo: Cia. das Letras, 1988, cit. por RICATTI, D. Apropriação social do espaço público. Um estudo comparativo. Revista Paisagem e Ambiente - Ensaios, v. 7, São Paulo: FAUUSP, 1995.
8 SENNET, R. (1988) cit. por RIGATTI, D. Apropriação social do espaço público. Um estudo Comparativo. Revista Paisagem e Ambiente-Ensaios, v. 7, São Paulo: 1994, FAUUSP, p. 146. 